\title{
Application of PCR-Based Methods to Dairy Products and to Non-Dairy Probiotic Products
}

\author{
Christophe Monnet ${ }^{1}$ and Bojana Bogovič Matijašić ${ }^{2}$ \\ 1UMR782 Génie et Microbiol. des Procédés Alimentaires INRA, AgroParisTech, \\ Thiverval-Grignon \\ 2Institute of Dairy Science and Probiotics, Biotechnical Faculty, University of Ljubljana \\ ${ }^{1}$ France \\ ${ }^{2}$ Slovenia
}

\section{Introduction}

Many types of cheeses and fermented dairy products are produced throughout the world. They contain various types of bacteria and fungi. In many cases, their exact microbiological composition is not well known because the deliberately added microorganisms are only part of the final microbiota. These microorganisms contribute to the manufacturing of the product (aroma compound production, acidification, impact on texture, colour etc.). Occasionally, dairy products may also be contaminated by spoilage microorganisms and pathogens. PCR-based methods have many interesting applications for dairy products. They can be used to detect, identify and quantify either unwanted or beneficial microorganisms. They can also provide culture-independent microbial fingerprints. Another application is the detection or the quantification of specific genes or groups of genes, such as those involved in the generation of the functional properties. In addition, the abundance of specific mRNA transcripts can be quantified by reverse transcription real-time PCR, which is very useful for a better understanding of the physiology and activity of the microorganisms present in dairy products.

Probiotics have been defined as "live microorganisms that, when administered in adequate amounts, confer a health benefit on the host" (FAO/WHO, 2002). The deficiencies of the quality of probiotic products in terms of too-low numbers or the absence of labelled species are commonly observed. The facts that probiotic functionality is a strain specific trait and that several probiotic strains have very similar phenotypic properties dictate the need for more powerful and rapid methods than conventional cultivation-based methods which have several disadvantages and very limited selectivity. The use of PCR based methods especially has greatly expanded during recent years.

Conventional PCR, combined with gel electrophoresis, has been successfully used for the genus-, species- or strain-specific determination of the presence of probiotic organisms in the products or in the biological samples (faeces). An important feature of probiotics, however, is the viability which is a prerequisite for the probiotic functionality. In this regard, a common DNA-based quantification by real-time PCR is not very useful for quantification purposes since the DNA released from dead or damaged cells also 
contributes to the results of analysis. One of the alternative approaches for selective detection of viable bacteria is the treatment of the samples with DNA-intercalating dyes such as ethidium monoazide (EMA) or propidium monoazide (PMA) that they can penetrate only into membrane-compromised bacterial cells or dead cells where they are by photo-activation covalently linked to DNA and prevent it from PCR amplification.

\section{Application of PCR-based methods to dairy products}

\subsection{Nucleic acid extraction from dairy products}

\subsubsection{DNA extraction}

Most of the DNA present in cheeses and other fermented dairy products is from the microorganisms that are present. This DNA has to be purified before performing PCR analyses. Dairy products are compositionally complex and there are several reports of dairy matrix-associated PCR inhibition (Niederhauser et al., 1992; Rossen et al., 1992; Herman and Deridder, 1993). One can distinguish two types of DNA extraction methods from dairy products: either direct extractions, or extractions after prior separation of the cells from the food matrix. In all cases, the DNA extraction protocols have to be adapted to the cheese under investigation.

Most methods described in the literature involve prior separation of the cells (Allmann et al., 1995; Herman et al., 1997; Serpe et al., 1999; Torriani et al., 1999; McKillip et al., 2000; Coppola et al., 2001; Ogier et al., 2002; Randazzo et al., 2002; Ercolini et al., 2003; Furet et al., 2004; Ogier et al., 2004; Baruzzi et al., 2005; Rudi et al., 2005; Rademaker et al., 2006; ElBaradei et al., 2007; Lopez-Enriquez et al., 2007; Parayre et al., 2007; Rossmanith et al., 2007; Trmcic et al., 2008; Van Hoorde et al., 2008; Alegría et al., 2009; Dolci et al., 2009; Zago et al., 2009; Le Dréan et al., 2010; Mounier et al., 2010). The recovery of cells from milks or fermented milks is easier to perform than from cheeses. In most cases, homogenisation of the samples and casein solubilisation is done in a sodium citrate solution, using a mechanical blender or glass beads, and the cells are recovered subsequently by centrifugation. Part of the fat is eliminated at this step because it forms a layer at the surface after centrifugation. Serpe et al. (1999) homogenised cheese samples in a Tris-HCl buffer containing the non-anionic detergent Tween 20 to emulsify the fat fraction of the sample. Depending on the type of cheese and the ripening stage, the cell pellet obtained after centrifugation may contain a large amount of caseins. These may be removed by washing the cell pellet with a buffer once or several times, and compounds such as Triton X-100 may be added for a better removal (Baruzzi et al., 2005). Caseins may also be eliminated by pronase digestion before recovery of the cells by centrifugation (Allmann et al., 1995; Furet et al., 2004; Ogier et al., 2004; Flórez and Mayo, 2006). It has been reported that the recovery of the bacterial cells may be improved by addition of polyethylene glycol during the homogenisation step (Stevens and Jaykus, 2004). A matrix lysis buffer containing urea and SDS combined with an homogenisation in a Stomacher laboratory blender has been used by Rossmanith et al. (2007) to recover Gram-positive cells from various food samples, including cheeses. In the procedure described by Herman et al. (1997) and Bonetta et al. (2008), bacterial cells are recovered from homogenised cheese by centrifugation after chemical extraction of fat and proteins. At the surface of some cheeses, for example smear-ripened cheeses, there is a high microbial density, and therefore, a simple surface scraping is sometimes sufficient to recover the microbial cells without need to eliminate the 
components from the cheese matrix (Rademaker et al., 2005). After their recovery, the cells are disrupted and DNA is purified from the lysed cells. Cell disruption may involve beadbeating, addition of lytic enzymes such as lysozyme, lyticase, mutanolysin or lysostaphine, addition chemical compounds, or a combination of these treatments. After cell lysis, purification of DNA may be performed by classical phenol/chloroform extraction. Phenol is a strong denaturant of proteins that leads to the partition of the proteins into the organic phase and at the interface of the organic and aqueous phases. Procedures avoiding the use of phenol, which is a toxic chemical, have been described. For example, Coppola et al. (2001), Rademaker et al. (2006), and Moschetti et al. (2001) used a commercial kit containing a synthetic resin which removes the cell lysis products that interfere with the PCR amplification. Baruzzi et al. (2005), Trmcic et al. (2008), and Furet et al. (2004) used a commercial kit in which proteins are eliminated by the use of a protein precipitation solution. Column-based or DNA-binding matrix purification methods have also been used (Rudi et al., 2005; Parayre et al., 2007; Zago et al., 2009; Le Dréan et al., 2010), sometimes as a final purification step after phenol/chloroform extraction (Stevens and Jaykus, 2004; LopezEnriquez et al., 2007). Separation of cells from the food matrix simplifies the subsequent steps of DNA extraction because most undesirable compounds such as matrix-associated reaction inhibitors are eliminated at the first step of extraction. In addition, large amounts of cheeses (for example more than 10 grams) can be processed in each extraction, which yields a large final amount of DNA. This is important in dairy products containing a low concentration of cells, for example at the initial steps of cheese-manufacturing, where direct DNA extraction is in most cases not possible. Furthermore, the separation of cells from the dairy food matrix eliminates in some cases the need for cultural enrichment prior to detection of pathogens. In contrast to RNA, it is unlikely that there is a large quantitative or qualitative change of the DNA present inside of the cells during the separation of the cells from the dairy food matrix. One of the drawbacks of the DNA extraction methods based on cell separation is that some DNA may be lost during the separation, due to cell lysis, especially for yeasts and Gram-negative strains.

In direct DNA extraction procedures (McKillip et al., 2000; Duthoit et al., 2003; Feurer et al., 2004a; Feurer et al., 2004b; Callon et al., 2006; Monnet et al., 2006; Delbes et al., 2007; Masoud et al., 2011), the cheese samples are first homogenised in a liquid solution by a method involving bead-beating, a mortar and pestle or other mechanical treatments. Efficient treatments of casein degradation and cell lysis, followed by phenol/chloroform extractions, are then needed to remove most contaminating compounds. Contaminating RNA can be removed by a treatment with RNase. Subsequent alcohol precipitation or column-based purification is then used to further purify and/to concentrate the DNA. Carraro et al. (2011) used a column-based purification method for direct extraction of DNA from cheese samples.

\subsubsection{RNA extraction}

Reverse transcription PCR analyses of RNA may be used in microbial diversity evaluation or for the detection or quantification of mRNA transcripts. Like for DNA, there are two types of extraction methods for RNA from dairy products, either direct extractions, or extractions after prior separation of the cells from the food matrix. The amount of RNA that can be recovered from dairy products is in general higher than for DNA. Indeed, the RNA content of microbial cells is higher than DNA. For example, in Escherichia (E.) coli, Bremer and Dennis (1996) reported a concentration varying from 7.6 to $18.3 \mu \mathrm{g}$ of DNA per $10^{9}$ cells, 
and from 20 to $211 \mu \mathrm{g}$ of RNA per $10^{9}$ cells, depending on the growth rates. Messenger RNA (mRNA) accounts for only $1-5 \%$ of the total cellular RNA. Compared to DNA, RNA is relatively unstable. This is largely due to the presence of ribonucleases (RNases), which break down RNA molecules. RNases are very stable enzymes and are difficult to inactivate. They can be present in the sample or introduced by contamination during RNA handling.

RNA extraction methods involving prior separation of the cells from cheeses and other dairy products have been used in several studies (Randazzo et al., 2002; Bleve et al., 2003; Sanchez et al., 2006; Bogovic Matijasic et al., 2007; Smeianov et al., 2007; Makhzami et al., 2008; Rantsiou et al., 2008a; Rantsiou et al., 2008b; Ulvé et al., 2008; Duquenne et al., 2010; Falentin et al., 2010; Cretenet et al., 2011; La Gioia et al., 2011; Masoud et al., 2011; Rossi et al., 2011; Taïbi et al., 2011). The recovery of microbial cells is done following similar protocols than for DNA extraction methods (see above). It is unlikely that the abundance of ribosomal RNA is modified during the cell separation procedure, but changes may occur with mRNA transcripts. Indeed, steady-state transcript levels are a result of both RNA synthesis and degradation. The mean half-life of E. coli mRNA measured by Selinger et al. (2003) was $6.8 \mathrm{~min}$. It is likely that mRNA synthesis and degradation occurs also during the separation of the cells from the food matrix. This is why all treatments before the complete inactivation of cellular processes should be as short as possible. Ulvé et al. (2008) separated bacterial cells from cheeses by homogenisation in a citrate solution at a temperature of +4 ${ }^{\circ} \mathrm{C}$, and extracted RNA using a column-based purification method after disruption of the cells by bead-beating. This method was compared to a direct RNA extraction, by measurement of the transcript abundance of 29 genes (Monnet et al., 2008). For most genes, there was no difference, but a higher level was measured for genes which expression is known to be modified by heat, acid, or osmotic stresses. Different methods of bacterial cell disruption were tested by Ablain et al. (2009) for the extraction of Staphylococcus (S.) aureus DNA and RNA. The best results were obtained with a combination of lysostaphin treatment and bead-beating. The cell pellets recovered from Camembert cheeses were treated with Chelex beads to remove contaminating compounds that may interfere in subsequent PCR analyses. Propionibacterium (P.) freundereichii, a species involved in Emmental cheese ripening, has a thick cell wall surrounded with capsular exopolysaccharides. For an efficient lysis of P. freundereichii cells recovered from cheeses, Falentin et al. (2010) used a combination of lysozyme treatment, bead-beating and phenol-chloroform extraction. Sanchez et al. (2006) recovered lactic acid bacteria cells from milk cultures after dispersion of caseins with EDTA, and extracted RNA using guanidinium thiocyanate-phenol-chloroform (commercial TRIzol reagent), a reagent that inactivates cellular processes and allows separation of RNA from DNA and proteins (Chomczynski and Sacchi, 1987). Duquenne et al. (2010) also used this type of extraction, after disruption of the cells by bead-beating. Bacterial cells may also be separated from cheese matrices using a Nycodenz gradient (Makhzami et al., 2008). In order to limit the changes in mRNA transcript composition inside of the cells during their separation from the dairy food matrix, Taïbi et al. (2011) added to the samples a stopping solution consisting of a mixture of phenol and ethanol. Smeianov et al. (2007) added the commercial reagent RNAprotect and rifampin, an antibiotic that suppresses the initiation of RNA synthesis, during the recovery of Lactobacillus ( $L b$.) helveticus cells from milk cultures.

So far, only a few studies have involved direct RNA extraction procedures from dairy products (Duthoit et al., 2005; Bonaiti et al., 2006; Monnet et al., 2008; Carraro et al., 2011; 
Trmcic et al., 2011). In the method described by Monnet et al. (2008), the cellular processes are stopped at the very beginning of the procedure, by addition of a guanidinium thiocyanate-phenol-chloroform solution to the cheese sample, and bead-beating is immediately performed. The reagent also inactivates RNases that may be present. At this step, the samples can be kept several weeks at $-80{ }^{\circ} \mathrm{C}$ without any decrease of RNA integrity, which is not possible when the cheese samples are frozen before the RNA extraction. It was found that the amount of cheese sample should not exceed $100 \mathrm{mg}$ per $\mathrm{ml}$ of reagent, as a higher ratio affects the quality and quantity of the purified RNA. The fat, caseins and DNA are removed after recovery of the aqueous phase which is formed after addition of chloroform. Subsequent acidic phenol-chloroform extraction and column-based purification is then performed to get RNA extracts suitable for reverse transcription PCR analyses and which can be stored several months at $-80^{\circ} \mathrm{C}$. Use of $7-\mathrm{ml}$ bead-beating tubes allows the processing of $500 \mathrm{mg}$ samples of cheese (Trmcic et al., 2011). In addition, several samples may be pooled and concentrated during the column-based purification step, which allows higher amounts of RNA to be recovered. With this procedure, sufficient amounts of RNA could be obtained for analysing gene expression of a Lactococcus (L.) lactis strain whose concentration was about $10^{8} \mathrm{CFU}$ per gram of cheese, with a corresponding RNA extraction yield of $4.9 \times 10^{-6} \mathrm{ng}$ RNA per CFU.

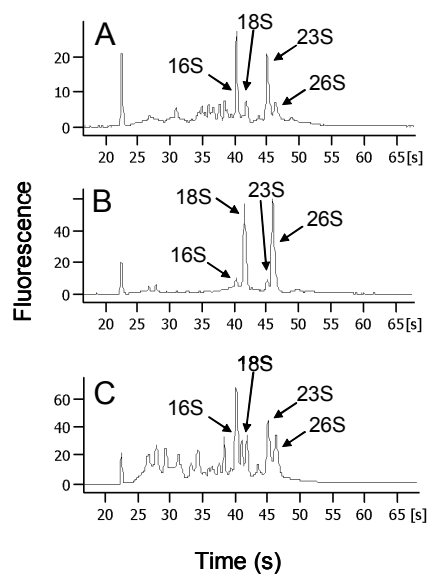

Fig. 1. RNA quality assessment with the Agilent Bioanalyzer: electrophoregrams of RNA preparations from various commercial smear-ripened cheeses using the method described by Monnet et al. (2008). 16S and 23S rRNA are from bacterial origin, and 18S and 26S rRNA are from fungi. Cheese B contains more RNA from fungi than cheeses A and C, and shows a higher overall RNA integrity.

The quality of the RNA samples has to be assessed. Absence of contaminating DNA can be checked by performing PCR amplifications with controls in which reverse transcription has not been performed. RNA concentration can be measured with a spectrophotometer at 260 $\mathrm{nm}$ or with a fluorometer after addition of fluorescent dyes. The RNA integrity is evaluated by gel electrophoresis or by automated capillary-based electrophoresis (e.g. 2100 Bioanalyzer equipment, Agilent). RNA is mostly constituted of ribosomal RNA (rRNA), and the sharpness of the small (16S or $18 \mathrm{~S}$ ) and large (23S or 26S) rRNA subunit bands is 
indicative of the global degree of RNA integrity. From the 2100 Bioanalyzer electrophoresis profile, a value, named RIN (RNA Integrity Number), is calculated. A RIN value of 10 corresponds to apparently intact material. RIN calculations can be done with either eukaryotic or prokaryotic RNA, but not when both types of RNA are present in the same sample, which would be the case for RNA samples from numerous types of cheeses. Examples of RNA electrophoregrams of RNA preparations from cheese samples are shown in Figure 1. During the ripening or storage of cheeses, some microbial populations may decline, for example by autolysis. This has a detrimental effect on RNA integrity and, in consequence, a poor RNA integrity level is not necessarily due to an inadequate sampling or RNA extraction procedure.

\subsection{Amplification targets}

All PCR analyses rely on amplification of DNA target sequences. Concerning PCR applications to dairy products, one can distinguish targets used for PCR-based microbial diversity evaluation, and targets for PCR analysis of specific microbial groups.

\subsubsection{Amplification targets for microbial diversity evaluation methods}

In methods of microbial diversity evaluation involving PCR, the amplification target is a sequence which has to be present in a large part of the bacterial or fungal population. The sequence variations allow the subsequent differentiation of the generated amplicons. In most cases, these techniques involve amplification of ribosomal RNA or housekeeping genes. In both prokaryotes and eukaryotes, rRNA genes usually show a high sequence homogeneity within a species (Liao, 1999), which explains why they are widely used in species identification and makes them a good target in molecular microbial diversity evaluation methods.

Bacterial 16S, $23 S$ and 5S rRNA genes are organised into a co-transcribed operon. The typical length of theses genes is $\sim 2900 \mathrm{bp}(23 \mathrm{~S}), \sim 1500 \mathrm{bp}(16 \mathrm{~S})$ and $\sim 120 \mathrm{bp}(5 \mathrm{~S})$. There are multiple copies (generally <10) of the rRNA genes in most bacteria, and the rRNA operons are generally dispersed throughout the chromosome. 16S rRNA sequences are frequently used as amplification target. All 16S rRNA genes share nine hypervariable (polymorphic) regions (Neefs et al., 1993) and the sequences are easily available from public databases. The hypervariable regions are flanked by conserved sequences, which can serve for amplification with "universal" primers (Baker et al., 2003). The variable V1 (Cocolin et al., 2004; Bonetta et al., 2008), V3 (Coppola et al., 2001; Ercolini et al., 2001; Ogier et al., 2002; Duthoit et al., 2003; Ercolini et al., 2003; Mauriello et al., 2003; Andrighetto et al., 2004; Ercolini et al., 2004; Feurer et al., 2004a; Feurer et al., 2004b; Lafarge et al., 2004; Ogier et al., 2004; Duthoit et al., 2005; Flórez and Mayo, 2006; Delbes et al., 2007; El-Baradei et al., 2007; Parayre et al., 2007; Abriouel et al., 2008; Ercolini et al., 2008; Gala et al., 2008; Van Hoorde et al., 2008; Alegría et al., 2009; Casalta et al., 2009; Dolci et al., 2009; Giannino et al., 2009; Mounier et al., 2009; Serhan et al., 2009; Dolci et al., 2010; Fontana et al., 2010; Van Hoorde et al., 2010; Masoud et al., 2011), V2 (Duthoit et al., 2003; Delbes and Montel, 2005; Saubusse et al., 2007), V4-V5 (Ercolini et al., 2003), V1-V3 (Randazzo et al., 2002), V4-V8 (Randazzo et al., 2006), V5-V6 (Le Bourhis et al., 2005; Le Bourhis et al., 2007) and V6-V8 (Randazzo et al., 2002; Ercolini et al., 2008; Nikolic et al., 2008; Randazzo et al., 2010) regions of the $16 \mathrm{~S}$ rRNA genes and the 16S-23S-spacer region (Coppola et al., 2001; Henri-Dubernet et al., 2004) are 
widely used in studies of the bacterial diversity of dairy products. Several distinct amplicons may be produced with some strains, due to differences in sequences of the rRNA copies.

In fungi, the internal transcribed spacer (ITS) is a region located between the 18S rRNA and 26S rRNA genes. It includes the 5.8S rRNA gene that splits the ITS into two parts: ITS1 and ITS2. The 18S, 5.8S, $26 \mathrm{~S}$ and $5 \mathrm{~S}$ rRNA sequences form up to hundreds of tandem repeats. The ITS region undergoes a faster rate of evolution than rRNA but its sequence remains homogenous within a species. The ITS2 region has been chosen as target for the study of the fungal biodiversity of smear-ripened cheeses (Mounier et al., 2010), and the ITS1 region for the study of the fungal diversity in cow, goat and ewe milk (Delavenne et al., 2011). Primers targeting regions of the 26S rRNA (Feurer et al., 2004b; Flórez and Mayo, 2006; Bonetta et al., 2008; Alegría et al., 2009; Dolci et al., 2009; Mounier et al., 2009) and the 18S rRNA (Callon et al., 2006; Arteau et al., 2010) were chosen to investigate the dominant yeast microflora of several types of cheeses.

Housekeeping genes are less used than rRNA in molecular studies of microbial diversity of dairy products. This is due to a lower availability in sequence databases. However, this may change in the near future, due to the rapid increase of the number of sequenced genomes. The $r p o B$ gene, encoding the RNA polymerase beta subunit has been used as a target for PCR-DGGE analysis to follow lactic acid bacterial population dynamics in cheeses (Rantsiou et al., 2004).

\subsubsection{Amplification targets for specific microbial groups}

Defined groups of microorganisms may be studied by amplification of specific targets, either by PCR or by real-time PCR. In the latter case, quantitative data can be obtained. The primers have to be designed so that amplification occurs only from DNA of the group of interest. As for PCR-based methods of microbial diversity evaluation, rRNA sequences are frequently used as target and the specificity may be evaluated in silico by comparing the rRNA sequences of the group of interest to that of other microorganisms that are present in the same habitat. A high level of specificity is achieved when there is a large sequence difference with non-target microorganisms for one or both of the PCR primers. Presence of mismatches near the $3^{\prime}$ of the primers ensures a better specificity than at the $5^{\prime}$ end. In addition, absence, or presence of only one or two $\mathrm{G}$ or $\mathrm{C}$ residues in the last five nucleotides at the $3^{\prime}$ end of primers, makes them less likely to hybridise transiently and to be available for non-specific extension by the DNA polymerase (Bustin, 2000). Corynebacterium casei cells could be quantified in cheeses by real-time PCR using a couple of primers targeting the V6 region of the 16S rRNA gene (Monnet et al., 2006). The assay was specific, as no amplification occurred with DNA from other Corynebacterium species present in cheeses. Primers targeting 16S rRNA genes were also used for the quantification of Carnobacterium cells in cheeses (Cailliez-Grimal et al., 2005), of L. lactis subsp. cremoris in fermented milks (Grattepanche et al., 2005), of Streptococcus (Str.) thermophilus and lactobacilli in fermented milks (Furet et al., 2004), of thermophilic bacilli in milk powder (Rueckert et al., 2005) and of bacterial species that can develop during the cold storage of milk (Rasolofo et al., 2010). Primers targeting the 16S-23S-spacer region were used for the specific detection of Clostridium tyrobutyricum in semi-soft and hard cheeses (Herman et al., 1997) and for the quantification of Listeria (List.) monocytogenes in foods, including fresh and ripened cheeses 
(Rantsiou et al., 2008a). rRNA sequence primers were also advised for the quantification of fungi in cheeses by real-time PCR. The variable D1/D2 domain of the 26S rRNA and the ITS1 region of the rRNA genes were targeted for the study of yeasts (Larpin et al., 2006; Makino et al., 2010) and Penicillium roqueforti (Le Dréan et al., 2010).

Primers of specific protein-encoding genes have been designed for the detection or the quantification of various groups of cheese microorganisms. Proteolytic lactobacilli can be detected in stretched cheeses by amplification of cell envelope proteinase genes (Baruzzi et al., 2005). Successful detection of specific bacteriocin biosynthesis genes could be achieved in microbial DNA extracted directly from several types of cheeses (Moschetti et al., 2001; Bogovic Matijasic et al., 2007; Trmcic et al., 2008). Allman et al. (1995) used specific PCR amplifications for the detection of pathogenic bacteria in dairy products. The targets were the List. monocytogenes listeriolysin O (hlyA), the E. coli heat-labile enterotoxin type $1(\mathrm{elt})$ and heat-stable toxin 1 (est), and the Campylobacter jejuni and Campylobacter coli flagellin proteins $(f l a A / f l a B)$. List. monocytogenes has also been quantified in gouda-like cheeses by real-time PCR, through hlyA gene amplification (Rudi et al., 2005). Another pathogen, Brucella spp., can be detected in soft cheeses by amplification of a fragment from a characteristic membrane antigen, protein BCSP-31 (Serpe et al., 1999). Thermonuclease (nuc) gene amplification has been applied for the quantification of $S$. aureus cells in cheese and milk samples (Hein et al., 2001; Hein et al., 2005; Alarcon et al., 2006; Studer et al., 2008; Aprodu et al., 2011). Manuzon et al. (2007) monitored the pool of tetracyclin resistance genes in retail cheeses in order to estimate the amount of tetracyclin resistant bacteria, which may pose a potential risk to consumers. Coliforms are a broad class of bacteria, whose presence can be used to assess the hygienic quality of foods. A real-time PCR detection method of all coliform species in a single assay has been set up (Martin et al., 2010). It is based on the amplification of a fragment of the beta-galactosidase gene (lacZ). Enterococcus (E.) gilvus, which is found in some types of cheeses, was quantified by real-time PCR using the phenylalanyl-tRNA synthase gene (pheS) as target (Zago et al., 2009). The procedure was selective against the highly phylogenetically related species E. malodoratus and E. raffinosus, and the pheS gene seems able to differentiate enterococcal species better than $16 \mathrm{~S}$ rRNA sequences. Histamine is a toxic biogenic amine that is sometimes involved in food poisoning. In order to quantify histamine-producing bacteria in cheeses by real-time PCR, Fernandez et al. (2006) designed consensual primers targeting the histidine decarboxylase $(h d c A)$ gene of Gram-positive species. Another type of undesired bacteria, Clostridium tyrobutyricum, responsible for late-blowing in hard and semi-hard cheeses, can be quantified in milk samples by real-time PCR amplification of the flagellin (fla) gene (Lopez-Enriquez et al., 2007).

It is likely that in the future, the increased availability of genome sequences will facilitate the selection of amplification targets for specific microbial groups. A good example is the study of Chen el al. (2010), in which real-time PCR primers were designed for the detection of Salmonella enterica strains. In this study, specific targets were generated by using a genomic analysis workflow, which compared 17 Salmonella enterica genome sequences to 827 nonSalmonella bacterial genomes.

\subsection{PCR-based methods for microbial diversity investigation}

Dairy products, especially cheeses, have diverse microbial compositions, which may be analysed by culture-dependent or culture-independent methods. Culture-independent 
methods involving PCR amplification are based on the analysis of DNA or RNA extracted from the food product. Even if they have several potential biases, they are faster and potentially more exhaustive than culture-dependent methods.

Denaturing gradient gel electrophoresis (DGGE), temperature gradient gel electrophoresis (TGGE) and temporal temperature gradient gel electrophoresis (TTGE) are widely used to study cheese microbial communities (Coppola et al., 2001; Ercolini et al., 2001; Ogier et al., 2002; Randazzo et al., 2002; Ercolini et al., 2003; Mauriello et al., 2003; Andrighetto et al., 2004; Cocolin et al., 2004; Ercolini et al., 2004; Henri-Dubernet et al., 2004; Lafarge et al., 2004; Ogier et al., 2004; Rantsiou et al., 2004; Le Bourhis et al., 2005; Flórez and Mayo, 2006; Randazzo et al., 2006; Cocolin et al., 2007; El-Baradei et al., 2007; Le Bourhis et al., 2007; Parayre et al., 2007; Abriouel et al., 2008; Bonetta et al., 2008; Ercolini et al., 2008; Gala et al., 2008; Henri-Dubernet et al., 2008; Nikolic et al., 2008; Rantsiou et al., 2008b; Van Hoorde et al., 2008; Alegría et al., 2009; Casalta et al., 2009; Dolci et al., 2009; Giannino et al., 2009; Serhan et al., 2009; Dolci et al., 2010; Fontana et al., 2010; Fuka et al., 2010; Randazzo et al., 2010; Van Hoorde et al., 2010; Masoud et al., 2011). Target sequences from rRNA or housekeeping genes are amplified and separated by electrophoresis. Separation is based on decreased electrophoretic mobility of partially melted double-stranded DNA molecules in polyacrylamide gels with a thermal gradient (TGGE) or which contain a gradient of DNA denaturants (DGGE). In TTGE, the separation is based on a temporal temperature gradient that increases in a linear fashion over the length of the electrophoresis time. Even if the DNA molecules have the same size, they may be separated because of their melting temperature behaviour, which depends on the sequence. A GC-rich clamp of about 40 bases is added at the $5^{\prime}$ end of one of the primers to stabilize the melting behaviour and to prevent the complete dissociation of the DNA fragments during electrophoresis. Assignment of the migration bands is done by comparison to a database containing the migration profiles of reference strains. DNA bands can be recovered from the gel and sequenced in order to confirm the assignments, or to find an assignment for bands which are not present in the database. DGGE, TGGE and TTGE profiles reveal a picture of the microbial diversity and can be used to compare different dairy products or to follow a given product at different fabrication stages. However, these methods are only semi-quantitative.

Single-strand conformation polymorphism-PCR (SSCP-PCR) is another PCR-based method for microbial diversity investigation that has been applied to dairy products (Duthoit et al., 2003; Feurer et al., 2004a; Feurer et al., 2004b; Delbes and Montel, 2005; Duthoit et al., 2005; Callon et al., 2006; Delbes et al., 2007; Saubusse et al., 2007; Mounier et al., 2009). This technique is based on the sequence-dependent differential intra-molecular folding of single strand DNA, which alters the migration speed of the molecules under non-denaturing conditions. Single strand DNA fragments having the same size may thus be separated, if their sequences generate different intramolecular interactions. After denaturation, the fluorescently labelled PCR products are separated using a capillary-based automated sequencer. In some cases, several stable conformations can be formed from one single strand DNA fragment, resulting in multiple bands. As for DGGE, TGGE and TTGE, SSCP provides community fingerprints that cannot be phylogenetically assigned directly. A database containing the migration profile of reference strains has to be created. One disadvantage of this technique is that the labelled single strand DNA fragments cannot be sequenced to confirm the assignations. 
Another PCR-based technique that has been applied to dairy products is terminal restriction fragment length polymorphism (TRFLP) (Rademaker et al., 2005; Rademaker et al., 2006; Arteau et al., 2010; Cogan and John, 2011). In TRFLP analyses, marker genes are amplified using one or two fluorescently labelled primers. The amplicons are then cut with one or several restriction enzymes and separated using a capillary-based automated sequencer. Only the end-labelled fragments are detected by the laser detector and their size can be determined by comparison with DNA size standards. One advantage of this technique is that the size of the fragments of any known DNA sequence can be determined in silico. This is why $16 \mathrm{~S}$ rRNA genes, whose sequences are easily available from public databases, are frequently used in TRFLP studies. As for SSCP, a drawback of capillary electrophoresisbased TRFLP is that bands remaining unknown cannot be extracted from the gel to be identified by DNA sequencing.

In denaturing high-performance liquid chromatography (DHPLC), PCR amplicons are partially denatured and separated on a liquid chromatography column which contains chemical agents that bind more strongly to double-stranded DNA molecules. Amplicons of the same size but with sequence differences resulting in modified melting behaviours will thus have different retention times. DHPLC analyses are rapid and the elution fraction corresponding to the different amplicons can be sequenced for confirmation or identification purposes. There are not many papers concerning DHPLC analyses of dairy products (Ercolini et al., 2008; Mounier et al., 2010; Delavenne et al., 2011), but this technique will probably be increasingly used in the future.

Bacterial diversity may also be assessed by sequencing clones libraries generated from $16 \mathrm{~S}$ rRNA gene amplification of DNA extracted from dairy products (Feurer et al., 2004a; Feurer et al., 2004b; Delbes et al., 2007; Rasolofo et al., 2010; Carraro et al., 2011). The main advantage of this technique is that no dedicated database is needed, as the sequences are already available in public genomic databases. In addition, in most cases, the 16S rRNA gene sequences permit assignments at the species level. But this technique is expensive and time-consuming, which is why it is not widely used. Second-generation DNA sequencing is a promising alternative to clone library sequencing (Cardenas and Tiedje, 2008). Masoud et al. (2011) studied the bacterial populations in Danish raw milk cheeses by pyrosequencing of tagged amplicons of the V3 and V4 regions of the 16S rRNA gene. After amplification of the 16S rRNA targets, a second PCR is done by using, for each sample, a different bar-coded primer. The amplified fragments of the different samples are then mixed and sequenced together, and the sequences are assigned to bacterial taxa. A very good agreement was found with the results of PCR-DGGE analysis. In addition, minor bacterial populations that were not detected by PCR-DGGE, were found by pyrosequencing. Furthermore, pyrosequencing provides a more reliable estimate of the relative abundance of the individual bacteria. Second-generation DNA sequencing appears thus to be a powerful and promising method, which will allow a deeper investigation of the bacterial populations in dairy products.

PCR-based methods for microbial diversity investigation can also be applied to RNA samples, after reverse transcription. As the ribosomal RNA content inside of the cells increases with the growth rate (Bremer and Dennis, 1996), one can assume that higher amounts of rRNA targets will be detected in active growing cells. In addition, since RNA is less stable than DNA, it will degrade more quickly in dead cells. In a study of the bacterial 
community from an artisanal Sicilian cheese, Randazzo et al. (2002) compared the intensity of bands from DNA and RNA-derived DGGE profiles and concluded that some species of the samples were not very metabolically active. Other studies of RNA profiles involving either DGGE (Rantsiou et al., 2008b; Dolci et al., 2010; Masoud et al., 2011), TTGE (Le Bourhis et al., 2007), SSCP (Le Bourhis et al., 2005), T-RFLP (Sanchez et al., 2006), clone library sequencing (Carraro et al., 2011) or pyrosequencing (Masoud et al., 2011) have been published.

\subsection{Real-time PCR methods}

Real-time PCR (qPCR) uses fluorescent reporter dyes to combine the amplification and detection steps of the PCR reaction in a single tube format. The assay relies on measuring the increase in fluorescent signal, which is proportional to the amount of DNA produced during each PCR cycle. A quantification cycle $(\mathrm{Cq})$ value is determined from the plot relating fluorescence against the cycle number. $\mathrm{Cq}$ corresponds to the number of cycles for which the fluorescence is higher than the background fluorescence. qPCR offers the possibility to quantify microbial populations through measurements of the abundance of a target sequence in DNA samples extracted from food products (Postollec et al., 2011). Combined with reverse transcription (RT), qPCR can also be used to estimate the amount of RNA transcripts.

Several applications of qPCR for the quantification of microbial populations in dairy products have been described (Table 1). In general, the experimental approach is the following: after extraction of DNA from the sample, qPCR is performed together with a standard curve, and the results are expressed as colony-forming-units (CFU), cell, or DNA target number per amount of dairy product. For an accurate quantification, several technical considerations have to be taken into account. First, the efficiency of recovery of the DNA from the dairy products should be constant and as high as possible. This may be verified in experiments where target cells are added to a control dairy matrix. Larpin et al. (2006) observed significant DNA losses during the extraction of DNA from cheese samples containing yeast species, and it appeared that cheese composition affected the extraction yields. DNA losses may occur during alcohol precipitation steps, especially in samples containing low amounts of DNA. A better recovery can be obtained by addition of coprecipitants such as exogenous DNA and glycogen. When column-based purification methods are used, it should be made sure that the amount of DNA loaded onto the columns does not exceed the column capacity. Another important technical consideration is that the amount of qPCR inhibitors in the DNA sample should be as limited as possible. One convenient way to evaluate the presence of inhibitors is to analyse by qPCR several dilutions of the DNA samples. The samples that need high dilution factors to reach the maximum PCR efficiency contain more inhibitors than those that need a lower dilution factor. The amount of PCR inhibitors has an impact on the detection level, as it determines the dilution factor that has to be applied in the qPCR assays. Absence of inhibitors can also be verified by inclusion of an internal amplification control (IAC). An IAC is a non-target DNA fragment that is co-amplified with the target sequence, ideally with the same primers used for the target. The forward and reverse target sequences are fused to both ends of a non-target fragment, to which a second fluorescent probe (the IAC probe) hybridises. The simultaneous use in a single reaction of two differently labelled fluorescent probes makes it 
possible to quantify the target and to assess PCR efficiency at the same time. If negative results are obtained for the target PCR, the absence of a positive IAC signal indicates that amplification has failed. Phenol extraction and repeated washing of alcohol-precipitated DNA pellets are efficient in reducing the impact of PCR inhibitors. In phenol-based purifications, the amount of PCR inhibitors may also be reduced by using a gel (Phase Lock Gel tubes) improving separation between the liquid and organic phases. For accurate qPCR quantification of microbial populations in dairy products, the level of cross-contaminations of DNA during DNA extraction and subsequent steps should be as limited as possible. This can be checked by adding several controls during the qPCR, such as water or DNA extracted from a dairy matrix that does not contain the target population. If complete absence of cross-contamination cannot be achieved, one may define a maximum $\mathrm{Cq}$ (quantification cycle) value, which is lower than the value obtained with the controls (e.g. five cycles lower), and over which the assay will not be considered. After qPCR amplification, melting curve analysis is carried out to confirm the absence of secondary amplification products. It is also possible to confirm amplification specificity by sequencing the resulting amplicon. Several types of standards may be used for calculating the concentration of targets in the dairy product. In the method used by Monnet et al. (2006), a standard curve is generated from different dilutions of a genomic DNA sample extracted from a pure culture of the target microorganism in liquid broth. The amount of target genomic DNA present in cheeses is then calculated and converted to colony-forming-units values, using a conversion factor determined from the pure culture DNA extract. Such calculation is valid only if the DNA recovery yield from cheeses is similar to that from cells grown in the liquid broth. Le Dréan et al. (2010) quantified Penicillium camemberti and Penicillium roqueforti mycelium in cheeses. To imitate cheese matrix effects, DNA was extracted from curd mixed with known amounts of fresh mycelium and was used as standard for further qPCR analyses. The mycelium concentration was then expressed as weight of mycelium per weight of cheese. Microbial cells may also be quantified using standard curves obtained with PCR-amplified targets. For example, Furet et al. (2004) determined the number of $16 \mathrm{~S}$ rRNA gene targets in DNA samples prepared from dairy products and converted this value to cell numbers, taking into account the number of $16 \mathrm{~S}$ rRNA gene copies in the chromosome of each species (http://rrndb.mmg.msu.edu, (Lee et al., 2009). Rasolofo et al. (2010) used a similar procedure for the quantification of Staphyloccous aureus, Aerococcus viridans, Acinetobacter calcoaceticus, Corynebacterium variabile, Pseudomonas fluorescens and Str. uberis in milk samples, except that standard curves were obtained from plasmids in which $16 \mathrm{~S}$ rRNA gene sequences of the target species were inserted.

The quantification limit values for microbial cells in dairy products reported for qPCR methods are heterogeneous. They depend on factors such as the type of dairy product (cheese or fermented milk), the efficiency of DNA extraction, the target microbial population and the target DNA sequence. A value of $10^{5} \mathrm{CFU} / \mathrm{g}$ has been reported for Corynebacterium casei (Monnet et al., 2006) and Carnobacterium species (Cailliez-Grimal et al., 2005), of 103-104 CFU/g for List. monocytogenes (Rantsiou et al., 2008a), of $10^{4} \mathrm{CFU} / \mathrm{g}$ for E. gilvus (Zago et al., 2009), and of $10^{3}$ cells $/ \mathrm{ml}$ for lactic acid bacteria (Furet et al., 2004). In some cases, higher amounts of microorganisms are measured with qPCR analyses than with classical agar counts, which may be explained by the fact that DNA from dead cells can also be amplified. In order to lower the detection levels of pathogens, it is possible to perform culture 
enrichment of the food samples before qPCR (Rossmanith et al., 2006; Chiang et al., 2007; Karns et al., 2007; O'Grady et al., 2009; Omiccioli et al., 2009). However, in that case, the results can only be used for detection, and not quantification.

\begin{tabular}{|c|c|c|c|}
\hline Target population & Target sequence & Food matrix & References \\
\hline Str. thermophilus & $\begin{array}{l}\text { rim } \mathrm{M} \text { (16S rRNA } \\
\text { processing protein) }\end{array}$ & $\begin{array}{l}\text { Commercial yoghurt } \\
\text { samples }\end{array}$ & (Ongol et al., 2009) \\
\hline L. lactis subsp. cremoris & 16S rRNA & $\begin{array}{l}\text { Experimental fermented } \\
\text { milks, mixed culture } \\
\text { with } L b \text {. rhamnosus and } \\
\text { L. lactis subsp. lactis } \\
\text { biovar. diacetylactis }\end{array}$ & $\begin{array}{l}\text { (Grattepanche et al., } \\
\text { 2005) }\end{array}$ \\
\hline $\begin{array}{l}\text { Str. thermophilus, Lb. } \\
\text { delbrueckii, Lb. casei, Lb. } \\
\text { paracasei, Lb. rhamnosus, } \\
\text { Lb. acidophilus, Lb. } \\
\text { johnsonii }\end{array}$ & $16 \mathrm{~S}$ rRNA & $\begin{array}{l}\text { Commercial fermented } \\
\text { milks }\end{array}$ & (Furet et al., 2004) \\
\hline Carnobacterium sp. & $16 \mathrm{~S}$ rRNA & $\begin{array}{l}\text { Artificially } \\
\text { contaminated cheeses } \\
\text { and commercial cheeses }\end{array}$ & $\begin{array}{l}\text { (Cailliez-Grimal et al., } \\
\text { 2005) }\end{array}$ \\
\hline Corynebacterium casei & $16 \mathrm{~S}$ rRNA & $\begin{array}{l}\text { Commercial smear- } \\
\text { ripened cheese }\end{array}$ & (Monnet et al., 2006) \\
\hline $\begin{array}{l}\text { P. freudenreichii and } L b \text {. } \\
\text { paracasei }\end{array}$ & $\begin{array}{l}\text { 16S rRNA, tuf (elongation } \\
\text { factor TU), GroL } \\
\text { (chaperonin GroEL) }\end{array}$ & $\begin{array}{l}\text { Experimental Emmental } \\
\text { cheese }\end{array}$ & (Falentin et al., 2010) \\
\hline $\begin{array}{l}\text { Str. thermophilus and } \\
\text { Lb. helveticus }\end{array}$ & $\begin{array}{l}\text { 16S rRNA, tuf (elongation } \\
\text { factor TU), GroL } \\
\text { (chaperonin GroEL) }\end{array}$ & $\begin{array}{l}\text { Experimental Emmental } \\
\text { cheese }\end{array}$ & (Falentin et al., 2012) \\
\hline E. gilvus & $\begin{array}{l}\text { pheS (phenylalanyl-tRNA } \\
\text { synthase }\end{array}$ & $\begin{array}{l}\text { Artisanal raw milk } \\
\text { cheeses }\end{array}$ & (Zago et al., 2009) \\
\hline E. faecium & $\begin{array}{l}\text { Conserved E. faecium } \\
\text { sequence }\end{array}$ & $\begin{array}{l}\text { Lebanese raw goat's } \\
\text { milk cheeses }\end{array}$ & (Serhan et al., 2009) \\
\hline $\begin{array}{l}\text { Clostridium } \\
\text { tyrobutyricum }\end{array}$ & fla (flagellin) & $\begin{array}{l}\text { Artificially } \\
\text { contaminated milks }\end{array}$ & $\begin{array}{l}\text { (Lopez-Enriquez et al., } \\
2007 \text { ) }\end{array}$ \\
\hline $\begin{array}{l}\text { Histamine-producing } \\
\text { bacteria }\end{array}$ & $\begin{array}{l}h d c \mathrm{~A} \text { (histidine } \\
\text { decarboxylase) }\end{array}$ & $\begin{array}{l}\text { Experimental cheeses } \\
\text { and commercial cheeses }\end{array}$ & $\begin{array}{l}\text { (Fernandez et al., 2006; } \\
\text { Ladero et al., 2008; } \\
\text { Ladero et al., 2009) }\end{array}$ \\
\hline $\begin{array}{l}\text { Tetracyclin resistant } \\
\text { bacteria }\end{array}$ & $\begin{array}{l}\text { tetS (tetracycline } \\
\text { resistance protein) }\end{array}$ & $\begin{array}{l}\text { Artificially } \\
\text { contaminated cheeses } \\
\text { and commercial cheeses }\end{array}$ & (Manuzon et al., 2007) \\
\hline Thermophilic bacilli & 16S rRNA & $\begin{array}{l}\text { Artificially } \\
\text { contaminated milk } \\
\text { powder }\end{array}$ & (Rueckert et al., 2005) \\
\hline Coliform species & lacZ (beta-galactosidase) & $\begin{array}{l}\text { Artificially } \\
\text { contaminated cheeses }\end{array}$ & (Martin et al., 2010) \\
\hline
\end{tabular}




\begin{tabular}{|c|c|c|c|}
\hline Target population & Target sequence & Food matrix & References \\
\hline E. coli O157:H7 & $\begin{array}{l}\text { eae (intimin adherence } \\
\text { protein) }\end{array}$ & $\begin{array}{l}\text { Market dairy food } \\
\text { samples }\end{array}$ & (Singh et al., 2009) \\
\hline E. coli $\mathrm{O} 157: \mathrm{H7}$ & virulence genes & Milk samples & (Karns et al., 2007) \\
\hline S. aureus & nuc (thermonuclease) & $\begin{array}{l}\text { Commercial food } \\
\text { samples, including } \\
\text { cheeses }\end{array}$ & (Omiccioli et al., 2009) \\
\hline S. aureus & nuc (thermonuclease) & $\begin{array}{l}\text { Artificially } \\
\text { contaminated and } \\
\text { naturally contaminated } \\
\text { milk samples }\end{array}$ & $\begin{array}{l}\text { (Studer et al., 2008; } \\
\text { Aprodu et al., 2011) }\end{array}$ \\
\hline S. aureus & nuc (thermonuclease) & $\begin{array}{l}\text { Artificially } \\
\text { contaminated cheeses, } \\
\text { bovine and caprine milk } \\
\text { samples }\end{array}$ & $\begin{array}{l}\text { (Hein et al., 2001; Hein } \\
\text { et al., 2005) }\end{array}$ \\
\hline S. aureus & $\begin{array}{l}\text { egc (enterotoxin gene } \\
\text { cluster) }\end{array}$ & $\begin{array}{l}\text { Artificially } \\
\text { contaminated and } \\
\text { naturally contaminated } \\
\text { milk samples }\end{array}$ & (Fusco et al., 2011) \\
\hline S. aureus genotype B & $\begin{array}{l}\text { sea (enterotoxin } \mathrm{A}), \text { sed } \\
\text { (enterotoxin D), lukE } \\
\text { (leucotoxin } \mathrm{E})\end{array}$ & Milk samples & (Boss et al., 2011) \\
\hline Brucella spp. & $\begin{array}{l}r n p \text { B (RNA component of } \\
\text { ribonuclease P), bcsp31 } \\
(311 \mathrm{kDa} \text { cell surface } \\
\text { protein) }\end{array}$ & Buffalo milk samples & $\begin{array}{l}\text { (Marianelli et al., 2008; } \\
\text { Amoroso et al., 2011) }\end{array}$ \\
\hline List. monocytogenes & $\begin{array}{l}\operatorname{prfA} \text { (transcriptional } \\
\text { activator) }\end{array}$ & $\begin{array}{l}\text { Commercial food } \\
\text { samples, including } \\
\text { cheeses }\end{array}$ & (Omiccioli et al., 2009) \\
\hline List. monocytogenes & 16S-23S-spacer region & $\begin{array}{l}\text { Various foods, } \\
\text { including milk and soft } \\
\text { cheese }\end{array}$ & (Rantsiou et al., 2008a) \\
\hline List. monocytogenes & hlyA (listeriolysin O) & $\begin{array}{l}\text { Artificially } \\
\text { contaminated cheeses } \\
\text { and commercial gouda- } \\
\text { like cheeses }\end{array}$ & (Rudi et al., 2005) \\
\hline List. monocytogenes & $\operatorname{ssr} \mathrm{A}(\mathrm{tmRNA})$ & $\begin{array}{l}\text { Commercial dairy } \\
\text { products }\end{array}$ & (O'Grady et al., 2009) \\
\hline $\begin{array}{l}\text { Mycobacterium avium } \\
\text { subsp. paratuberculosis }\end{array}$ & MAP F57 sequence & $\begin{array}{l}\text { Commercial raw milk } \\
\text { cheeses }\end{array}$ & (Stephan et al., 2007) \\
\hline $\begin{array}{l}\text { Mycobacterium avium } \\
\text { subsp. paratuberculosis }\end{array}$ & Insertion element IS900 & $\begin{array}{l}\text { Milk samples and } \\
\text { commercial cheeses }\end{array}$ & $\begin{array}{l}\text { (Rodríguez-Lázaro et } \\
\text { al., 2005; Donaghy et } \\
\text { al., 2008; Herthnek et } \\
\text { al., 2008; Slana et al., } \\
\text { 2008; Botsaris et al., } \\
\text { 2010) }\end{array}$ \\
\hline
\end{tabular}




\begin{tabular}{|c|c|c|c|}
\hline Target population & Target sequence & Food matrix & References \\
\hline Mycoplasma bovis & $\begin{array}{l}\text { uvrC } \\
\text { (deoxyribodipyrimidine } \\
\text { photolyase) }\end{array}$ & Bovine milk samples & (Rossetti et al., 2010) \\
\hline $\begin{array}{l}\text { S. aureus, Aerococcus } \\
\text { viridans, Acinetobacter } \\
\text { calcoaceticus, } \\
\text { Corynebacterium } \\
\text { variabile, Pseudomonas } \\
\text { fluorescens and Str. } \\
\text { uberis }\end{array}$ & $16 \mathrm{~S}$ rRNA & $\begin{array}{l}\text { Milk during cold } \\
\text { storage }\end{array}$ & (Rasolofo et al., 2010) \\
\hline $\begin{array}{l}\text { Salmonella spp., List. } \\
\text { monocytogenes and } E . \\
\text { coli O157 }\end{array}$ & $\begin{array}{l}\text { Salmonella spp: } t \text { tr cluster } \\
\text { (tetrathionate reductase } \\
\text { genes) } \\
\text { List. monocytogenes: hlyA } \\
\text { (listeriolysin O) } \\
\text { E. coli O157: rfbE } \\
\text { (perosamine synthetase } \\
\text { homolog) }\end{array}$ & $\begin{array}{l}\text { Artificially } \\
\text { contaminated milk }\end{array}$ & (Omiccioli et al., 2009) \\
\hline $\begin{array}{l}\text { Debaryomyces hansenii, } \\
\text { Geotrichum candidum, } \\
\text { Kluyveromyces sp., } \\
\text { Yarrowia lipolytica }\end{array}$ & $\begin{array}{l}\text { G. candidum: cgl } \\
\text { (cystathionine-gamma- } \\
\text { lyase), } \\
\text { Kluyveromyces sp.: lac4 } \\
\text { Y. lipolytica: } \\
\text { topoisomerase II }\end{array}$ & $\begin{array}{l}\text { Commercial Livarot } \\
\text { cheeses }\end{array}$ & (Larpin et al., 2006) \\
\hline $\begin{array}{l}\text { Penicillium roqueforti } \\
\text { and Penicillium } \\
\text { camemberti }\end{array}$ & $\begin{array}{l}\text { P. roqueforti: ITS1 region } \\
\text { of rRNA } \\
P \text {. camemberti: beta-tubulin } \\
\text { gene }\end{array}$ & $\begin{array}{l}\text { Model cheeses and } \\
\text { commercial } \\
\text { Camembert-type } \\
\text { cheeses }\end{array}$ & (Le Dréan et al., 2010) \\
\hline $\begin{array}{l}\text { Candida albicans, } \\
\text { Candida glabrata, } \\
\text { Candida parapsilosis, } \\
\text { Candida tropicalis, } \\
\text { Clavispora lusitaniae, } \\
\text { Filobasidiella } \\
\text { neoformans, Issatchenkia } \\
\text { orientalis, Trichosporon } \\
\text { asahii, and Trichosporon } \\
\text { jirovecii }\end{array}$ & $\begin{array}{l}\text { D1/D2 domain of } 26 S \\
\text { rRNA }\end{array}$ & $\begin{array}{l}\text { Artificially } \\
\text { contaminated } \\
\text { fermented milk }\end{array}$ & (Makino et al., 2010) \\
\hline $\begin{array}{l}\text { Lb. delbrueckii } \\
\text { bacteriophages }\end{array}$ & bacteriophage lysin genes & $\begin{array}{l}\text { Artificially } \\
\text { contaminated milk } \\
\text { samples }\end{array}$ & (Rossetti et al., 2010) \\
\hline
\end{tabular}

Table 1. Examples of applications of qPCR for the quantification or detection of microbial populations in dairy products.

The study of gene expression within natural environments such as dairy products is an emerging field in microbial ecology that is especially promising in the study of bacterial function even though only a few applications of reverse-transcription qPCR to dairy 
products have been described so far (Table 2). Reverse-transcription qPCR experiments involve the following steps: RNA extraction, evaluation of RNA integrity, DNase treatment, reverse-transcription and qPCR (Nolan et al., 2006; Bustin et al., 2009). Reverse transcriptions can be done with random hexamers, specific primers or oligo-dT primers (only for eukaryotic mRNA). Two types of quantification methods may be used: absolute quantification and relative quantification (Wong and Medrano, 2005; Nolan et al., 2006; Bustin et al., 2009; Cikos and Koppel, 2009). Absolute quantification is based on comparison of $\mathrm{Cq}$ values with a standard curve generated from the target sequence. The determination of a concentration of target RNA in the samples requires generating a standard curve with known amounts of RNA targets (and not DNA) that have been transcribed in vitro. This is necessary because the efficiencies of reverse transcription reactions are not known and vary from target to target. In addition, the reverse transcription step has been proposed as the source of most of the variability in reverse-transcription qPCR (Freeman et al., 1999), owing to the sensitivity of reverse transcriptase enzymes to inhibitors that may be present in the samples. As the production of in vitro-transcribed RNA standards is fastidious and timeconsuming, and there is no guarantee that the reverse transcription efficiency with these standards will be similar to that with the biological RNA samples, there are not many reports of absolute quantification in reverse transcription qPCR involving RNA standards. Absolute quantification of RNA transcripts with DNA standards (e.g. with standards that have not been reverse transcribed) is sometimes used. In that case, the exact number of RNA targets in the biological samples cannot be determined and results are expressed as "DNA gene equivalent" (Nicolaisen et al., 2008) or "cDNA". If it is assumed that the reverse transcription efficiencies for a given target are constant whatever the sample, these results can be used to compare the abundance of the same RNA target in several samples. Smeianov et al. (2007) used absolute quantification to compare the expression of $L b$. helveticus genes during growth in milk and in MRS medium. In these experiments, the amount of cDNA before qPCR was standardised. Ulvé et al. (2008) standardised the amount of RNA before reverse transcription and compared the Cq values obtained for genes of $L$. lactis in cheeses at different ripening times. Even if it is not possible by this method to quantitatively compare the abundance of different RNA targets in the same sample (which would need in vitro-transcribed RNA standards), large differences in abundance may be shown. Direct comparisons of Cq values with a standardised amount of RNA have also been used to investigate the effect of cell separation from the cheese matrix before RNA extraction (Monnet et al., 2008). Bleve et al. (2003) observed a correlation between standard plate counts of yeasts and moulds present in spoiled commercial food products and the Cq values obtained by reverse transcription qPCR analysis with primers targeting the fungal actin gene. To follow gene expression of $P$. freudenreichii and $L b$. paracasei during cheese-making, Falentin et al. (2010) measured the amount of cDNA copies of the target sequence after reverse transcription, and divided this value by the corresponding number of cells, which was measured by qPCR analysis of DNA extracted from the cheese samples. From these analyses, it could be concluded that the metabolic activity of Lb. paracasei cells reached a maximum during the first part of ripening, whereas the maximum activity of $P$. freudenreichii was reached later. A similar approach was used for the study of the metabolic activity of Lb. helveticus and Str. thermophilus cells during the ripening of Emmental cheese (Falentin et al., 2012). 
One disadvantage of all absolute quantification analyses is the significant reduction in the number of experimental samples that can be run on a single plate because a standard curve has to be included in each reaction run. In relative quantification methods, the amount of RNA targets in samples is expressed relative to the amount of the same target present in another sample, which is designated as the calibrator. This calibrator is chosen among the samples being compared (Cikos and Koppel, 2009). The advantage of this method is that standard curves don't have to be included in each run. However, this does not compensate for variations in reverse transcription efficiency and in RNA extraction efficiency from one sample to another. To compensate for this sample-to-sample variation, the quantity of RNA target is usually normalised to the quantity of one or several internal reference genes. These reference genes must be shown to be stable under the experimental conditions being examined, and are evaluated using software programmes such as geNorm or Bestkeeper. Two ideal reference genes are expected to have an identical expression ratio in all samples, whatever the experimental conditions. In the geNorm procedure (Vandesompele et al., 2002), the $\mathrm{Cq}$ values of each sample are transformed into relative quantities (Q) with a calibrator (cal) sample and using the gene-specific PCR efficiency (E), calculated as follows: $\mathrm{Q}=\mathrm{E}$ (calCq - sampleCq). Normalisation is then applied by dividing the relative quantities of genes of interest by the geometric mean of the relative quantities of selected reference genes (normalisation factor). The 16S rRNA gene was used as reference gene to follow the expression of L. lactis nisin genes in a model cheese (Trmcic et al., 2011). Several groups of genes could be distinguished based on expression profiles as a function of time, which contributed to a better knowledge of the regulation of nisin biosynthesis. For normalisation of gene transcripts from Pseudomonas spp., Enterococcus spp., Pediococcus (P.) pentosaceus and Lb. casei during the manufacturing of an experimental Montasio cheese, Carraro et al. (2011) used one couple of primers targeting the 16S rRNA of all bacteria present. The calculated fold-change does not reflect the specific gene expression of each population, but rather an expression taking into account the total amount of 16S rRNA. Cretenet et al. (2011) quantified the expression of several genes from L. lactis in model cheeses made from ultrafiltered milk, using gyrB (DNA gyrase subunit B) as reference gene. The histidine decarboxylase gene $(h d c A)$ present in certain Str. thermophilus strains is involved in the synthesis histamine, a biogenic amine which may be accumulated in cheeses. The expression of $h d c A$ was studied under conditions common to cheese-making, using the gene encoding the alpha subunit of the RNA polymerase (rpoA) as reference gene (Rossi et al., 2011). In this case, the stability of reference gene expression was assessed by absolute quantification of the transcripts obtained from fixed amounts of RNA. Up-regulation of $h d c A$ occurred in the presence of free histidine and salt, and repression after thermisation. In bacteria, the gene encoding the elongation factor TU (tuf) is frequently used as reference gene in reverse transcription qPCR analyses. The expression of this gene by L. lactis was investigated in model cheeses by relative quantification using the total amount of RNA for normalisation, i.e. with reverse transcriptions performed with a fixed amount of RNA (Monnet et al., 2008). In this case, one has to check that potential biases, such as differences of reverse transcription efficiencies among the samples being studied, do not interfere. With this method, the calculated gene expression does not represent the expression relative to other mRNA transcripts, but rather the expression relative to the ribosomal RNA, which form most RNA. A large decrease of $t u f$ expression, up to 100-fold, was observed after a few days. This decrease probably reflected the global decrease of mRNA transcription in the cheese matrix, after the end of growth of L. lactis. Duquenne et al. (2010) were able to quantify the 
expression of Staphyloccus aureus enterotoxins genes in model cheeses using a set of three stably expressed reference genes. A similar approach was applied for the study of the growth of L. lactis subsp. cremoris strains under conditions simulating cheddar cheese manufacture (Taïbi et al., 2011) and for the study of iron acquisition by Arthrobacter arilaitensis in experimental cheeses (Monnet et al., 2012).

\begin{tabular}{|c|c|c|c|}
\hline Target population & Target sequence & Food matrix & References \\
\hline L. lactis subsp. lactis & $\begin{array}{l}16 \mathrm{~S} \text { rRNA, } 23 \mathrm{~S} \text { rRNA } \\
\text { and } 27 \text { protein-encoding } \\
\text { genes }\end{array}$ & Experimental cheeses & (Monnet et al., 2008) \\
\hline L. lactis & $\begin{array}{l}11 \text { genes involved in } \\
\text { nisin biosynthesis }\end{array}$ & Experimental cheeses & (Trmcic et al., 2011) \\
\hline L. lactis subsp. lactis & $\begin{array}{l}\text { tuf (elongation factor } \\
\text { Tu), gapB } \\
\text { (glyceraldehyde 3- } \\
\text { phosphate } \\
\text { dehydrogenase), purM } \\
\text { (phosphoribosyl- } \\
\text { aminoimidazole } \\
\text { synthetase), cysK } \\
\text { (cysteine synthase), ldh } \\
\text { (L-lactate } \\
\text { dehydrogenase), citD } \\
\text { (citrate lyase acyl-carrier } \\
\text { protein), gyrA (DNA } \\
\text { gyrase subunit A) }\end{array}$ & Experimental cheeses & (Ulvé et al., 2008) \\
\hline L. lactis subsp. lactis & $\begin{array}{l}\text { bcaT, } \operatorname{cod} Y, \operatorname{ser} A, \text { cysK, } \\
\text { gltD, lac } C, \text { gap } A, \text { gap } B, \\
\text { pdhB, aldB, butA, noxE, } \\
\text { murF, dnaK, chi } A, \text { pepN, } \\
\text { gyrB, pi139, pi302 }\end{array}$ & Experimental cheeses & (Cretenet et al., 2011) \\
\hline L. lactis subsp. cremoris & $\begin{array}{l}\text { bcaT, clpE, dnaG, gapA, } \\
\text { glyA, groEL, oppA, pepQ, } \\
\text { purD, ldh, holin1, holin2 }\end{array}$ & Experimental cheeses & (Taïbi et al., 2011) \\
\hline Lb. helveticus & $\begin{array}{l}\operatorname{asn} A, \operatorname{cys} E, \operatorname{dap} A, \operatorname{ser} A, L- \\
\text { ldh, } \operatorname{clpP}, \text { oppA, oppC } \\
\text { pepO2, pepT2, prtH, } \\
\text { prtH2, purA, pyrR }\end{array}$ & Milk cultures & (Smeianov et al., 2007) \\
\hline Str. thermophilus & $\begin{array}{l}h d c A \text { (histidine } \\
\text { decarboxylase) }\end{array}$ & Milk cultures & (Rossi et al., 2011) \\
\hline Str. thermophilus & $\begin{array}{l}t d c A \text { (tyrosine } \\
\text { decarboxylase) }\end{array}$ & Milk cultures & (La Gioia et al., 2011) \\
\hline $\begin{array}{l}\text { P. freudenreichii and } L b \text {. } \\
\text { paracasei }\end{array}$ & $\begin{array}{l}\text { 16S rRNA, tuf } \\
\text { (elongation factor TU), } \\
\text { GroL (chaperonin } \\
\text { GroEL) }\end{array}$ & $\begin{array}{l}\text { Experimental } \\
\text { Emmental cheese }\end{array}$ & (Falentin et al., 2010) \\
\hline
\end{tabular}




\begin{tabular}{|c|c|c|c|}
\hline Target population & Target sequence & Food matrix & References \\
\hline $\begin{array}{l}\text { Lb. helveticus and Str. } \\
\text { thermophilus }\end{array}$ & $\begin{array}{l}\text { 16S rRNA, tuf } \\
\text { (elongation factor Tu), } \\
\text { groL (chaperonin GroEL) }\end{array}$ & Experimental cheeses & (Falentin et al., 2012) \\
\hline Arthrobacter arilaitensis & $\begin{array}{l}\text { 16S rRNA, gyrB (DNA } \\
\text { gyrase subunit B), ftsZ } \\
\text { (cell division protein), } \\
\text { recA (recombinase A), } \\
\text { rpoB (RNA polymerase } \\
\text { beta chain), rpoA (RNA } \\
\text { polymerase alpha } \\
\text { chain), tuf (elongation } \\
\text { factor Tu), dnaG (DNA } \\
\text { primase), and genes } \\
\text { involved in iron } \\
\text { acquisition }\end{array}$ & Experimental cheeses & (Monnet et al., 2012) \\
\hline Str. thermophilus & $\begin{array}{l}\text { two-component system } \\
\text { genes }\end{array}$ & Milk cultures & $\begin{array}{l}\text { (Thevenard et al., } \\
\text { 2012) }\end{array}$ \\
\hline $\begin{array}{l}\text { Lb. casei, P. pentosaceus, } \\
\text { Str. thermophilus, } \\
\text { Enterococcus spp., } \\
\text { Pseudomonas spp. }\end{array}$ & 16S rRNA & $\begin{array}{l}\text { Montasio cheese } \\
\text { manufacturing }\end{array}$ & (Carraro et al., 2011) \\
\hline Yeasts and moulds & actin gene & $\begin{array}{l}\text { Commercial food } \\
\text { products, including } \\
\text { milk and yoghurt }\end{array}$ & (Bleve et al., 2003) \\
\hline S. aureus & $\begin{array}{l}\text { gyrB (DNA gyrase } \\
\text { subunit B), ftsZ (cell } \\
\text { division protein), hu } \\
\text { (DNA-binding protein), } \\
\text { rplD (50S ribosomal } \\
\text { protein L4), recA } \\
\text { (recombinase A), sodA } \\
\text { (superoxide dismutase), } \\
\text { gap (glyceraldehyde-3- } \\
\text { phosphate } \\
\text { dehydrogenase), rpoB } \\
\text { (RNA polymerase beta } \\
\text { chain), pta (phosphate } \\
\text { acetyltransferase), tpi } \\
\text { (triose phosphate } \\
\text { isomerase), sea } \\
\text { (enterotoxin A), sed } \\
\text { (enterotoxin D) }\end{array}$ & Experimental cheeses & $\begin{array}{l}\text { (Duquenne et al., } \\
\text { 2010) }\end{array}$ \\
\hline S. aureus & $\begin{array}{l}16 \mathrm{~S} \text { rRNA, nuc } \\
\text { (thermonuclease) }\end{array}$ & $\begin{array}{l}\text { Artificially } \\
\text { contaminated } \\
\text { Camembert cheeses }\end{array}$ & $\begin{array}{l}\text { (Ablain et al., 2009) } \\
\text { (Fumian et al., 2009) }\end{array}$ \\
\hline Noroviruses & $\begin{array}{l}\text { ORF1-ORF2 junction } \\
\text { region }\end{array}$ & $\begin{array}{l}\text { Artificially } \\
\text { contaminated cheeses }\end{array}$ & (Fumian et al., 2009) \\
\hline
\end{tabular}

Table 2. Examples of applications of reverse-transcription qPCR to dairy products. 


\section{Application of PCR-based methods to non-dairy probiotic products}

\subsection{Nucleic acid extraction from non-dairy probiotic products}

Probiotic products comprise probiotic dairy products and probiotic food supplements which appear in several forms, like powders, capsules, tablets, suspensions etc. containing the lyophilised, dried or microencapsulated bacterial cells. Since an overview of the nucleic acid extraction and PCR application in dairy products in general have already been addressed in this chapter, we focus here on the non-dairy probiotic products such as food supplements or pharmaceutical preparations. The protocols of DNA or RNA extraction from different probiotic products have to be properly adapted to the matrix in order to achieve satisfactory yield and efficient PCR amplification. It is important to evaluate whether the components of the product other than microbial cells influence the extraction and amplification steps. Probiotic formulations may contain polysaccharides, salts, oils (microencapsulated) or proteins (milk-based) which have been demonstrated to affect the extraction or inhibit amplification by direct interaction with DNA or by interference with the polymerases used in PCR. DNA isolation from the samples containing milk which is among the common ingredients of probiotic formulations, requires multiple steps such as centrifugation, heating or cation exchange to remove proteins, calcium ions and fats (Cressier and Bissonnette, 2011).

An increasing amount of non-dairy probiotic products contain microencapsulated probiotic cells. Depending on the microencapsulation technique (spray-drying, coacervation, cocrystallisation, molecular inclusion) and the matrix and coating materials used, the physicochemical properties of microcapsules differ much. Microcapsules containing probiotic bacteria are often insoluble in water, in order to allow their controlled release in the intestine. In order to enable the release of bacterial cells and DNA to the medium, particular treatment and diluents different from the commonly used (Ringer solution, peptone saline solution, water) are needed, for example addition of emulsifiers (anionic, cationic) or nonionic detergents such as Tween 80 (Champagne et al., 2010; Burgain et al., 2011).

When probiotics are microencapsulated in alginate beads, a calcium-binding solution such as phosphates or citrates is most often used to dissolve the particles. Another problem presents dried, fat-based spray-coated probiotic bacteria which can be found in different products in a form of powders, capsules, tablets, suspension in oil or for example in chocolate. One of the concerns could be that fat coating on the particles would prevent hydration, resulting in unsatisfactory recovery of viable bacteria and under-estimation of CFU counts.

The selection of rehydration method and solutions significantly influenced the results of CFU determination by plate counting in microencapsulated Lb. rhamnosus R0011 or Bifidobacterium (B.) longum ATCC 15708 cultures spray-coated with fat. Tween 80 did not result in direct improvement of the recovery of CFU, while the addition of fat improved it. The authors concluded that the methods appropriate for the analysis of free cells in dried probiotics may not be optimal for the analysis of spray-coated ME cultures (Champagne et al., 2010). The recovery of dried probiotic cultures is greatly dependent on the reconstitution conditions. Maximum recovery of B.standardised longum NCC3001 was achieved at 30-min reconstitution at $\mathrm{pH} 8$, in the presence of $2 \% 1$-arabinose and with a ratio of 1:100 of powder to diluent, while $L b$. johnsonii La1 showed highest recovery after reconstitution, when mixed 
with maltodextrin at $\mathrm{pH} 4$ (Muller et al., 2010). The published data on the optimisation of DNA isolation from microencapsulated bacteria are scarce however since the first step of bacterial DNA isolation from the product is separation of the bacterial cells from the matrix, the conditions and procedures found suitable for viable count (CFU) determination in samples containing microencapsulated bacteria may be a good starting point also for DNA isolation.

Due to the specificities described above, there are no universal standard procedures and media/buffers for the rehydration of probiotic products and quantification of probiotics in such products, either by the assessment of viable counts or by PCR-based methods. Often the authors do not explain in detail the preparation of the samples of probiotic products but refer to the standards such as ISO 6887-1:2000 on the general rules for the preparation of the initial suspension and decimal dilutions of food and animal feeding stuffs, or ISO 68875:2010 including specific rules for the preparation of milk and milk products which are applicable also to dried milk products and milk-based infant foods. ISO 20838:2006 provides the overall framework for qualitative methods for the detection of food-borne pathogens in or isolated from food and feed matrices using the polymerase chain reaction (PCR), but can also be applied to other matrices, for example environmental samples, or to the detection of other microorganisms under investigation. However, the standards do not contain detailed protocols which have to be developed specifically considering the properties of the products.

Champagne et al. (2011) recently published recommendations for the viability assessment of probiotics as concentrated cultures and in food matrices by plate counting, but the recommendations relevant for the DNA isolation are not available.

Microbial analysis of probiotic food supplements and pharmaceutical preparations require standardised and accurate procedures for the reactivation of dehydrated cultures. Among the resuspension buffers, $1 / 4$ Ringer solution with or without cysteine $(0,05 \%)$, peptone physiological solution $(0.1 \% \mathrm{wt} / \mathrm{vol}$ peptone, $0.85 \% \mathrm{wt} / \mathrm{vol} \mathrm{NaCl})$ or water are used most often (Temmerman et al., 2003; Masco et al., 2005; Masco et al., 2007; Kramer et al., 2009; Bogovic Matijasic et al., 2010). For the preparation of mesophilic cultures for qPCR analysis, which present similar medium as probiotic formulations, Friedrich and Lenke (2006) used PBS and sodium citrate ( $1 \% \mathrm{wt} / \mathrm{vol})$.

Usually the probiotic cells are removed by centrifugation from the product matrix before being exposed to the cell lysis. Drisko et al. (2005) exceptionally resuspended the products directly in TE buffer (10 mM Tris- $\mathrm{HCl}$ with $\mathrm{pH}$ 8.0, $1 \mathrm{mM}$ EDTA) and proceeded with SDS and proteinase $\mathrm{K}$ treatment. After the lysis of bacterial cells, phenol/chloroform extraction or different kits such as the QIAamp®DNA stool mini kit (Qiagen), the NucleoSpin ${ }^{\circledR}$ food kit (Macherey-Nagel), Wizard Genomic DNA Purification kit (Promega), Maxwell 16 Cell DNA Purification Kit (Promega) are most commonly used.

Lyophilised probiotic products can also be resuspended in water and the suspension added directly in PCR mixture, without previous isolation of bacterial DNA. This way Vitali et al. (2003) for instance carried out the real-time PCR quantification of three Bifidobacterium strains in a pharmaceutical product VSL-3 containing lyophilised bacteria and excipients. 


\begin{tabular}{|c|c|c|c|c|}
\hline Target population & Method & $\begin{array}{l}\text { Target } \\
\text { sequence }\end{array}$ & $\begin{array}{l}\text { Form of } \\
\text { product }\end{array}$ & References \\
\hline $\begin{array}{l}\text { B. bifidum, Bacillus coagulans, Lb. } \\
\text { acidophilus, Lb. casei, Lb. } \\
\text { delbrueckii subsp. bulgaricus, Lb. } \\
\text { delbrueckii subsp. lactis, Lb. } \\
\text { helveticus, Lb. kefiri, Lb. paracasei, } \\
\text { Lb. plantarum, Lb. reuteri, Lb. } \\
\text { rhamnosus, Lb. salivarius, Lc. } \\
\text { Lactis, } P \text {. freudenreichii subsp. } \\
\text { freudenreichii, P. freudenreichii } \\
\text { subsp. shermanii, Str. thermophilus }\end{array}$ & PCR & $\begin{array}{l}\text { 16S rDNA, } \\
16 \mathrm{~S}-23 \mathrm{~S} \text { IS, } \\
\text { htrA, pepIP, } \\
\text { rpoA }\end{array}$ & $\begin{array}{l}\text { capsules, } \\
\text { tablets, } \\
\text { powder } \\
\text { sachets, } \\
\text { chewable } \\
\text { tablets, } \\
\text { bottled } \\
\text { products }\end{array}$ & (Aureli et al., 2010) \\
\hline Lb. gasseri, E. faecium, B. infantis & $\begin{array}{l}\text { real-time } \\
\text { PCR }\end{array}$ & $\begin{array}{l}\text { 16S rDNA, } \\
\text { 16S-23S IS }\end{array}$ & capsules & $\begin{array}{l}\text { (Bogovic Matijasic } \\
\text { et al., 2010) }\end{array}$ \\
\hline $\begin{array}{l}\text { Lb. acidophilus, Lc. lactis, E. } \\
\text { faecium, B. bifidum, B. lactis, Lb. } \\
\text { rhamnosus, Lb. helveticus, Bacillus } \\
\text { cereus, Lb. delbrueckii subsp. } \\
\text { bulgaricus, Str. thermophilus }\end{array}$ & $\begin{array}{l}\text { PCR- } \\
\text { DGGE }\end{array}$ & $16 \mathrm{~S}$ rDNA & $\begin{array}{l}\text { capsules, } \\
\text { tablets }\end{array}$ & $\begin{array}{l}\text { (Temmerman et al., } \\
\text { 2003) }\end{array}$ \\
\hline $\begin{array}{l}\text { Lb. delbrueckii subsp. bulgaricus, } \\
\text { Lb. salivarius, Lb. plantarum, Lb. } \\
\text { rhamnosus, Lb. acidophilus, B. } \\
\text { infantis, Lb. casei, Lb. brevis, B. } \\
\text { lactis, Str. thermophilus, B. bifidum }\end{array}$ & PCR & $\begin{array}{l}16 \mathrm{~S} \text { rDNA, } \\
\text { 16S-23S IS, } \\
\beta \text {-galactosidase } \\
\text { gene }\end{array}$ & not stated & (Drisko et al., 2005) \\
\hline $\begin{array}{l}\text { Lb. acidophilus, B. animalis subsp. } \\
\text { lactis }\end{array}$ & $\begin{array}{l}\text { real-time } \\
\text { PCR }\end{array}$ & $16 \mathrm{~S}$ rDNA & capsules & $\begin{array}{l}\text { (Kramer et al., } \\
\text { 2009) }\end{array}$ \\
\hline $\begin{array}{l}\text { B. animalis subsp. lactis, B. longum } \\
\text { biotype longum, B. bifidum, B. } \\
\text { animalis subsp. lactis, B. bifidum, } \\
\text { B. breve, B. longum biotype } \\
\text { longum, B. longum biotype } \\
\text { infantis }\end{array}$ & $\begin{array}{l}\text { nested } \\
\text { PCR- } \\
\text { DGGE }\end{array}$ & $16 \mathrm{~S}$ rDNA & not stated & (Masco et al., 2005) \\
\hline $\begin{array}{l}\text { B. animalis subsp. lactis, B. breve, } \\
\text { B. bifidum, B. longum biotype } \\
\text { longum }\end{array}$ & $\begin{array}{l}\text { real-time } \\
\text { PCR }\end{array}$ & $\begin{array}{l}16 \mathrm{~S} \text { rDNA, } \\
\text { recA genes }\end{array}$ & $\begin{array}{l}\text { capsules, } \\
\text { powders, } \\
\text { tablets }\end{array}$ & (Masco et al., 2007) \\
\hline $\begin{array}{l}\text { B.standardised infantis } Y 1 \text {, } \\
\text { B.standardised breve } Y 8, \\
\text { B.standardised longum } Y 10\end{array}$ & $\begin{array}{l}\text { PCR, } \\
\text { real-time } \\
\text { PCR }\end{array}$ & $\begin{array}{l}\text { 16S rDNA, } \\
16 S-23 S \text { IS }\end{array}$ & $\begin{array}{l}\text { powder } \\
\text { sachets }\end{array}$ & (Vitali et al., 2003) \\
\hline $\begin{array}{l}\text { Lb. acidophilus, B.standardised } \\
\text { infantis v. liberorum, Ent. faecium, } \\
\text { B. bifidum, Lb. delbrueckii subsp. } \\
\text { bulgaricus, Str. thermophilus, B. } \\
\text { longum, B. breve, Lb. rhamnosus, L. } \\
\text { lactis }\end{array}$ & PCR & $\begin{array}{l}\text { 16S rDNA, } \\
16 S-23 S \text { IS }\end{array}$ & $\begin{array}{l}\text { Capsules, } \\
\text { powder, } \\
\text { pastilles }\end{array}$ & $\begin{array}{l}\text { (Bogovic Matijasic } \\
\text { and Rogelj, 2006) }\end{array}$ \\
\hline
\end{tabular}

Table 3. Examples of applications of PCR, qPCR or PCR-DGGE to probiotic food supplements or pharmaceutical products. 


\subsection{Detection or quantification of probiotics in non-dairy probiotic products by PCR}

\subsubsection{PCR detection of labelled probiotic bacteria in probiotic food supplements or pharmaceutical preparations}

Probiotic food supplements and pharmaceutical preparations are widespread and commercially important. The most important parameters of their quality are appropriate labelling of probiotic bacteria and adequate number of them in the products. This is still not such an easy task since standardised methods are available for only avery limited number of probiotic bacteria in dairy products such as Lb. acidophilus (ISO 20128/IDF 192:2006) and Bifidobacterium (ISO 29981/IDF 220:2010). This speaks in favour of using molecular techniques which are rapid, sensitive and specific. Several PCR tests for detection of pathogens in foods have been validated, harmonised, and commercialised to make PCR a standard tool used by food microbiology laboratories (Maurer, 2011; Postollec et al., 2011). In the probiotic field there is still much to do in terms of the application of PCR-based methods for the control of probiotic products. Conventional PCR is very useful for the detection of labelled species or genera in the probiotic products. While several applications of this technique in food, including probiotic fermented dairy products, can be found in the literature (Table 1), the reports dealing with probiotic food supplements or pharmaceutical preparations are still few (Table 3). Among the targets which have been used in PCR analysis of probiotic products in the form of capsules, tablets or powders there are most often 16S rDNA or 16S-23S intergenic spacer (IS) regions which appear in the cells in multiple copies, contain several species or genus-specific regions and enable higher sensitivity than single copy genes. In addition to the ribosomal genes, several monocopy genes have also already been used for PCR or real-time PCR of probiotics such as htrA, pepIP, rpoA, $\beta$-galactosidase gene, or recA gene (Table 3). Primers for $h$ tr $A$-trypsin-like serine protease gene were used originally by Fortina et al. (2001), for pepIP-immunopeptidase proline gene pepIP by Torriani et al. (2007) and for rpoA-RNA polymerase alpha subunit gene by Naser et al. (2007). The main advantage of the application of genes that usually appear in one copy is that they enable accurate quantification by real-time PCR also in the mixed populations of bacteria belonging to different species, while the number of rRNA genes copies differs among the species.

\subsubsection{Real-time PCR quantification of probiotic bacteria in non-dairy products}

It is well known that many food ingredients, including fats, proteins, divalent cations, and phenolic compounds, can act as PCR inhibitors. Some of the ingredients may also hinder the adequate microbial cell separations from the sample matrix. Another common problem is non-heterogeneous distribution of target cells in the samples, the presence of microbial aggregates which are difficult to disrupt or high amounts of non-target microbiota (BrehmStecher et al., 2009). In the analysis of probiotic products in general the usual approach is to separate first the bacterial target cells from the matrix, which in the case of lyophilised or dried products is usually not such a difficult task and may be successfully performed by rehydration of the samples followed by centrifugation. This way most of the potential inhibitory compounds are removed. Inhibitors are further removed also during the nucleic acids purification steps which have been described above. However, as some of the inhibitors may still be present in the samples intended for quantitative PCR (qPCR) analysis, the examination of possible inhibition of PCR reaction is always required. 
In order to exclude possible inhibition, Masco et al. (2007) prepared bacteria-free sample matrices of the food supplement, spiked them with known quantities of reference bifidobacteria and compared the standard curve slopes and efficiencies obtained during PCR amplification of pure cultures and spiked samples. The finding that amplification of pure cultures and spiked samples was equally efficient indicated that the product's matrix did not have a significant impact on DNA extraction and subsequent real-time PCR performance.

Similarly Kramer et al. (2009) prepared the standard curves from the mixture of bacterial cells of $\mathrm{Lb}$. acidophilus or B. animalis ssp. lactis with a suspension of filler ingredients of probiotic capsules. The concentrations of Beneo synergy $(0,73 \%)$, saccharose $(0,11 \%)$, dextrose anhydrous $(0,10 \%)$, microcrystalline cellulose $(0,026 \%)$, potato starch $(0,026 \%)$ and Mg-stearate $(0,019 \%)$ in the standard samples were the same as in the 1:100 diluted product. In addition, the negligible effect of the product ingredients on the PCR amplification efficiency was demonstrated also by the comparison of the standard curves prepared from the DNA derived from pure cultures of from the suspensions of cultures in the simulated filler.

In a further study of the same probiotic pharmaceutical preparation (Bogovič Matijašić, not published) the authors treated $1 \%(\mathrm{w} / \mathrm{v})$ suspension of the product with heat (two times 120 ${ }^{\circ} \mathrm{C} / 15 \mathrm{~min}$ ). The total DNA in the suspension was mostly degraded as was demonstrated by real-time PCR amplification using Lactobacillus (LactoR'F/LBFR, (Songjinda et al., 2007) ) or Bifidobacterium (Bif-F/Bif-R, (Rinttila et al., 2004). The two-times autoclaved suspension was spiked with either of the two strains isolated from the product, and after that DNA isolated from the spiked suspension was used for the generation of standard curves.

Bogovič Matijašić et al. (2010) prepared the simulated matrix with $\mathrm{Mg}$ stearate $(0.22 \%)$, lactose $(0.39 \%)$ and starch $(0.39 \%)$ corresponding to the concentrations of these ingredients in a 100 -fold sample of the product in capsules. DNA was isolated by different procedures from the standard samples containing simulated matrix with a known amount of added probiotic bacteria of Lb. gasseri, B. infantis or Ec. faecium. When DNA was isolated by heat treatment $\left(100{ }^{\circ} \mathrm{C} / 5 \mathrm{~min}\right)$ of the standard bacterial suspensions in $1 \%$ Triton $\mathrm{X}-100$, the ingredients of the prepared suspension affected the real-time PCR result. Since the filler ingredients themselves did not show any fluorescence interaction when included directly in PCR reactions, the lower concentration of probiotic determined in real-time PCR was attributed to the less effective DNA extraction by heat-triton treatment due to the presence of $\mathrm{Mg}$ stearate, lactose and starch. Any effect was however observed when DNA was isolated by the Maxwell system (Promega) based on the use of MagneSil paramagnetic particles (Bogovic Matijasic et al., 2010).

In all studies presented in Table 3, the real- time PCR analyses were performed by SYBR ${ }^{\circledR}$ Green I chemistry. The species specificity of the PCR was ensured by using species-specific oligonucleotide primers and additionally validated by melting point analysis.

\subsubsection{Viability determination of probiotics by PCR-based methods}

The viability of probiotic bacteria is traditionally assessed by plate counting which has several limitations, such as unsatisfactory selectivity, too-low a recovery, long incubation time, underestimation of cells in aggregates or chains morphology etc. (Breeuwer and Abee, 
2000). Real-time PCR has a potential to replace conventional enumeration of probiotic bacteria, used for routine monitoring of quality of a probiotic product and for stability studies. However, since probiotic bacteria have to be viable to exert their activity the contribution of DNA arising from non-viable cells to the result of quantification has to be excluded.

An approach using PMA or EMA treatment of the samples before the DNA isolation seems promising in this regard. Such DNA-intercalating dyes are able to bind upon exposure to bright visible light to DNA and, consequently, to inhibit PCR amplification of the DNA which is free or inside the bacterial cells with the damaged membrane. Although probiotic bacteria in the products are represented in different stages not only as viable or dead (Bunthof and Abee, 2002), the most important criterion for distinguishing between viable and irreversibly damaged cells is membrane integrity. The treatment of bacteria with EMA as a promising tool of DNA-based differentiation between viable and dead pathogenic bacteria was first proposed by Nogva et al. in 2003 (Nogva et al., 2003). In the following years several applications of this approach have been reported, where the method was optimised for different complex media such as faeces, fermented milk and environmental samples (Garcia-Cayuela et al., 2009; Fittipaldi et al., 2011; Fujimoto et al., 2011). Since ethidium monoazide has been suggested as being toxic to some viable cells, PMA has been proposed as a more appropriate alternative to EMA (Nocker et al., 2006; Fujimoto et al., 2011).

The PMA treatment in combination with real-time PCR was applied for determination of probiotic strains $\mathrm{Lb}$. acidophilus LA-5 and B. animalis ssp. lactis BB-12 bacteria in a pharmaceutical formulation in the form of capsules (Kramer et al., 2009). The possible effects of the ingredients of the product on PMA treatment of the samples including the photoactivation step, as well as on the PCR reaction were evaluated in the study. The ability of PMA to inhibit amplification of DNA derived from damaged bacterial cells was confirmed on bacteria from pure cultures of Lb. acidophilus or B. animalis ssp. lactis in a $1 \%(\mathrm{w} / \mathrm{v})$ suspension of ingredients which are otherwise present in the product and on probiotic product $(1 \% \mathrm{w} / \mathrm{w})$. Other examples of direct application of PMA-real time PCR on the lyophilised probiotic products have not been found in the literature. The efficient PMA treatment of fermented dairy products containing the same two strains, Lb. acidophilus LA-5 and B. animalis ssp. lactis BB-12, have also been described (Garcia-Cayuela et al., 2009). In order to eliminate the milk ingredients prior to the PMA treatment, the samples were adjusted to $\mathrm{pH} 6.5$ with $1 \mathrm{M} \mathrm{NaOH}$, then casein micelles were dispersed by theaddition of 1 $\mathrm{M}$ trisodium citrate, and bacterial cells were harvested by centrifugation. The obtained cells were resuspended in water, treated with PMA and used for DNA isolation. Fujimoto et al. (2010) evaluated strain-specific qPCR with PMA treatment for quantification of viable $B$. breve strain Yakult (BbrY) in human faeces. The quantification was carried out on faecal samples spiked with BbrY strain, on the BbrY culture and on the faecal samples collected from the healthy volunteers who ingested a commercially available fermented milk product containing BbrY, once daily for 10 days. They confirmed the use of a combination of qPCR with PMA treatment and BbrY-specific primers as a quick and accurate method for quantification of viable BbrY in faecal samples (Fujimoto et al., 2011).

Viable probiotics may be enumerated also by a qPCR-based method targeting mRNA of different housekeeping genes. The advantage of using mRNA targets over the use of DNA 
or rRNA is mainly in the instability of mRNA molecules which is degraded soon after the cell death. Reimann et al. (2010) demonstrated in B. longum NCC2705 a good correlation between measured mRNA levels of cysB and purB, two constitutively expressed housekeeping genes and plate counts. The 400-bp fragment of purB was degraded more quickly than the 57-bp fragments of cysB and purB, and is therefore a better marker of cell viability (Reimann et al., 2010).

With the availability of new highthroughput molecular technologies such as microarray technology and next-generation sequencing, new possibilities are now open to further development of the viability PCR approach also in the probiotic field, as has already been similarly demonstrated for selected pathogenic bacteria in environmental samples (Nocker et al., 2009; Nocker et al., 2010).

\subsection{Strain-specific detection or quantification of probiotics}

While species- or genus-specific primers are not so difficult to construct, the problem arises when we intend to confirm different strains of the same species in the product. A variety of PCR-based genotyping techniques such as random amplified polymorphic DNA analysis (RAPD), repetitive sequence-based PCR (rep-PCR), pulsed-field gel electrophoresis (PFGE), amplified fragment length polymorphism (AFLP) ribotyping etc., are successfully used everywhere to distinguish different strains also closely related among each other ( $\mathrm{Li}$ et al., 2009). The genotyping methods, however, require the cultivation of pure cultures of examined strains and do not enable quantification. For PCR quantification of individual probiotic strains in the probiotic products or different environments (faeces, mucosa...) strain specific primers or probes are needed. So far it has been very difficult to find strainspecific genome sequences as a target for the construction of strain-specific primers or probes.

In the study of Vitali et al. (2003), the 16S rDNA and 16S-23S rDNA-targeted strain-specific primers were designed for the quantitative detection of $B$. infantis $\mathrm{Y} 1, B$. breve $\mathrm{Y} 8$ and $B$. longum Y10 used in a pharmaceutical probiotic product VSL-3. These were applied in PCR, and real-time PCR techniques with the selected primers were employed for the direct enumeration of the bifidobacteria in the probiotic preparation and for studying their kinetic characteristics in batch cultures (Vitali et al., 2003).

Maruo et al. (2006) generated a L. lactis subsp. cremoris FC-specific primer pair by using a specific 1164-bp long RAPD band sequence. The specificity of this primer pair has been proven with 23 L. lactis subsp. cremoris strains and 20 intestinal bacterial species, and realtime PCR determination of FC strain in the faeces was demonstrated to be successful. Marzotto et al. (2006) selected specific primers for the putative probiotic strain Lb. paracasei A LcA-Fw and LcA-Rv from the terminal regions of the 250-bp RAPD fragment sequence tested the selectivity with 20 different Lactobacillus species and $39 \mathrm{Lb}$. paracasei strains. The primers were successfully applied in PCR analysis of faecal samples (Marzotto et al., 2006).

Strain-specific PCR primers and probes for real-time PCR and for conventional PCR were designed based on the sequence of RAPD products, also for Lb. rhamnosus GG which is one of the most studied probiotic strains (Ahlroos and Tynkkynen, 2009). The strain specificity of the primers was verified in conventional PCR using a set of strains - six Lb. rhamnosus, one $L b$. casei and one $L b$. zeae, while the applicability of the GG strain-specific primer probe 
set was confirmed on the human faecal samples by LightCycler (Roche Diagnostics) realtime PCR.

A similar approach was applied to B. breve strain Yakult (BbrY) by Fujimoto et al. (2011). The specificity of the BbrY-specific primer set was confirmed by PCR using DNA from 112 bacterial strains belonging to $B$. breve species, of other Bifidobacterium species and representatives of 11 other genera. The BbrY-specific primers were used in a real-time PCR with PMA treatment to measure the number of BbrY in the faeces of subjects who drank a fermented milk product containing BbrY (Fujimoto et al., 2011).

The qPCR method based on the amplification of a strain-specific DNA fragment identified by suppressive subtractive hybridisation was developed recently for specific and sensitive monitoring of P. acidipropionici P169 in animal feed and rumen fluid by Peng et al. (2011). The specificity and amplification efficiency was assessed on 44 Propionibacterium strains and also in complex microbial communities containing P. acidipropionici P169 (Peng et al., 2011).

Certain strains have specific features that distinguish them from the other related strains, such as for example bacteriocin production. Treven et al. (submitted) evaluated the possibility of using bacteriocin-specific primers for the detection and quantification of $L b$. gasseri K7 probiotic strain, a producer of at least two two-component bacteriocins (Zoric Peternel et al., 2010). Two pairs of primers, namely GasA_401/610F/R and GasB_26102807F/R showed specificity for total gene cluster of gassericin K7 A (Genbank EF392861) or gassericin K7 B (Genbank AY307382) respectively as established by PCR assays using DNA of 18 reference strains belonging to $L b$. acidophilus group and 45 faecal samples of adult volunteers who have never consumed K7 strain. GasA_401/610F/R primers were also found to be especially useful also for real-time PCR quantification of gassericin K7 A gene cluster in faecal samples and also for Lb. gasseri K7-specific detection or quantification in the biological samples (Treven et al. submitted).

\section{Conclusions}

Microorganisms are very important components of fermented dairy products, including probiotic food, as well as of probiotic food supplements and pharmaceutical preparations. PCR-based methods have become indispensable in the microbiological analysis of these groups of products. In the field of fermented dairy products, several applications based on PCR have been developed with the aim to detect, identify and quantify either unwanted bacteria, which may negatively influence the sensory properties of food or may be pathogenic, or beneficial microorganisms which are added as starter cultures or probiotic cultures. Beside PCR analysis of DNA, reverse transcription real-time PCR analysis of mRNA transcript is particularly useful, especially in studies of the physiology and functionality of bacteria in the food environment. In the probiotic field, PCR is expected to be increasingly applied in quality control in terms of detection and quantification of labelled probiotic bacteria in probiotic food supplements or pharmaceutical preparations, and in viability analysis of probiotics in the products. In addition to the already well-established methods described in this chapter, ever easier access to the next generation sequencing may replace some PCR approaches as molecular fingerprint, metagenomic and metatranscriptomic analyses. The access to increasing number of complete bacterial genomes may also facilitate the strain-specific analysis of probiotics or other bacteria through identification of strain-specific sequences. 


\section{References}

Ablain, W., Hallier Soulier, S., Causeur, D., Gautier, M., Baron, F., 2009. A simple and rapid method for the disruption of Staphylococcus aureus, optimized for quantitative reverse transcriptase applications: Application for the examination of Camembert cheese. Dairy Sci. Technol. 89, 69-81.

Ablain, W., Hallier Soulier, S., Causeur, D., Gautier, M., Baron, F., 2009. A simple and rapid method for the disruption of Staphylococcus aureus, optimized for quantitative reverse transcriptase applications: Application for the examination of Camembert cheese. Dairy Sci. Technol. 89, 69-81.

Abriouel, H., Martin-Platero, A., Maqueda, M., Valdivia, E., Martinez-Bueno, M., 2008. Biodiversity of the microbial community in a Spanish farmhouse cheese as revealed by culture-dependent and culture-independent methods. Int. J. Food Microbiol. 127, 200-208.

Ahlroos, T., Tynkkynen, S., 2009. Quantitative strain-specific detection of Lactobacillus rhamnosus GG in human faecal samples by real-time PCR. J. Appl. Microbiol. 106, 506-514.

Alarcon, B., Vicedo, B., Aznar, R., 2006. PCR-based procedures for detection and quantification of Staphylococcus aureus and their application in food. J. Appl. Microbiol. 100, 352-364.

Alegría, Á., Álvarez-Martín, P., Sacristán, N., Fernández, E., Delgado, S., Mayo, B., 2009. Diversity and evolution of the microbial populations during manufacture and ripening of Casín, a traditional Spanish, starter-free cheese made from cow's milk. Int. J. Food Microbiol. 136, 44-51.

Allmann, M., Hofelein, C., Koppel, E., Luthy, J., Meyer, R., Niederhauser, C., Wegmuller, B., Candrian, U., 1995. Polymerase chain reaction (PCR) for detection of pathogenic microorganisms in bacteriological monitoring of dairy products. Res. Microbiol. 146, 85-97.

Amoroso, M.G., Salzano, C., Cioffi, B., Napoletano, M., Garofalo, F., Guarino, A., Fusco, G., 2011. Validation of a Real-time PCR assay for fast and sensitive quantification of Brucella spp. in water buffalo milk. Food Control 22, 1466-1470.

Andrighetto, C., Marcazzan, G., Lombardi, A., 2004. Use of RAPD-PCR and TTGE for the evaluation of biodiversity of whey cultures for Grana Padano cheese. Lett. Appl. Microbiol. 38, 400-405.

Aprodu, I., Walcher, G., Schelin, J., Hein, I., Norling, B., Rådström, P., Nicolau, A., Wagner, M., 2011. Advanced sample preparation for the molecular quantification of Staphylococcus aureus in artificially and naturally contaminated milk. Int. J. Food Microbiol. 145, S61-S65.

Arteau, M., Labrie, S., Roy, D., 2010. Terminal-restriction fragment length polymorphism and automated ribosomal intergenic spacer analysis profiling of fungal communities in Camembert cheese. Int. Dairy J. 20, 545-554.

Aureli, P., Fiore, A., Scalfaro, C., Casale, M., Franciosa, G., 2010. National survey outcomes on commercial probiotic food supplements in Italy. Int. J. Food Microbiol. 137, 265273.

Baker, G.C., Smith, J.J., Cowan, D.A., 2003. Review and re-analysis of domain-specific $16 S$ primers. J. Microbiol. Meth. 55, 541-555. 
Baruzzi, F., Matarante, A., Caputo, L., Morea, M., 2005. Development of a cultureindependent polymerase chain reaction-based assay for the detection of lactobacilli in stretched cheese. J. Rapid Meth. Aut. Mic. 13, 177-192.

Bleve, G., Rizzotti, L., Dellaglio, F., Torriani, S., 2003. Development of reverse transcription (RT)-PCR and real-time RT-PCR assays for rapid detection and quantification of viable yeasts and molds contaminating yogurts and pasteurized food products. Appl. Environ. Microbiol. 69, 4116-4122.

Bogovic Matijasic, B., Koman Rajsp, M., Perko, B., Rogelj, I., 2007. Inhibition of Clostridium tyrobutyricum in cheese by Lactobacillus gasseri. Int. Dairy J. 17, 157-166.

Bogovic Matijasic, B.B., Obermajer, T., Rogelj, I., 2010. Quantification of Lactobacillus gasseri, Enterococcus faecium and Bifidobacterium infantis in a probiotic OTC drug by realtime PCR. Food Control 21, 419-425.

Bogovic Matijasic, B.B., Rogelj, I., 2006. Demonstration of suitability of probiotic products An emphasis on survey of commercial products obtained on Slovenian market. Agro Food Ind. Hi-Tech 17, 38-40.

Bonaiti, C., Parayre, S., Irlinger, F., 2006. Novel extraction strategy of ribosomal RNA and genomic DNA from cheese for PCR-based investigations. Int. J. Food Microbiol. 107, 171-179.

Bonetta, S., Bonetta, S., Carraro, E., Rantsiou, K., Cocolin, L., 2008. Microbiological characterisation of Robiola di Roccaverano cheese using PCR-DGGE. Food Microbiol. 25, 786-792.

Boss, R., Naskova, J., Steiner, A., Graber, H.U., 2011. Mastitis diagnostics: Quantitative PCR for Staphylococcus aureus genotype B in bulk tank milk. J. Dairy Sci. 94, 128-137.

Botsaris, G., Slana, I., Liapi, M., Dodd, C., Economides, C., Rees, C., Pavlik, I., 2010. Rapid detection methods for viable Mycobacterium avium subspecies paratuberculosis in milk and cheese. Int. J. Food Microbiol. 141, S87-S90.

Breeuwer, P., Abee, T., 2000. Assessment of viability of microorganisms employing fluorescence techniques. Int. J. Food Microbiol. 55, 193-200.

Brehm-Stecher, B., Young, C., Jaykus, L.A., Tortorello, M.L., 2009. Sample Preparation: The Forgotten Beginning. J. Food Prot. 72, 1774-1789.

Bremer, H., Dennis, P.P., 1996. Modulation of chemical composition and other parameters of the cell by growth rate, in: Neidhart, F.C. (Ed.), Escherichia coli and Salmonella: Cellular and Molecular Biology, ASM Press, Washington DC, pp. 1553-1569.

Bunthof, C.J., Abee, T., 2002. Development of a flow cytometric method to analyze subpopulations of bacteria in probiotic products and dairy starters. Appl. Environ. Microbiol. 68, 2934-2942.

Burgain, J., Gaiani, C., Linder, M., Scher, J., 2011. Encapsulation of probiotic living cells: From laboratory scale to industrial applications. J. Food Eng. 104, 467-483.

Bustin, S.A., 2000. Absolute quantification of mRNA using real-time reverse transcription polymerase chain reaction assays. J. Mol. Endocrinol. 25, 169-193.

Bustin, S.A., Benes, V., Garson, J.A., Hellemans, J., Huggett, J., Kubista, M., Mueller, R., Nolan, T., Pfaffl, M.W., Shipley, G.L., Vandesompele, J., Wittwer, C.T., 2009. The MIQE Guidelines: Minimum Information for Publication of Quantitative Real-Time PCR Experiments. Clin. Chem. 55, 611-622.

Cailliez-Grimal, C., Miguindou-Mabiala, R., Leseine, M., Revol-Junelles, A.M., Milliere, J.B., 2005. Quantitative polymerase chain reaction used for the rapid detection of 
Carnobacterium species from French soft cheeses. FEMS Microbiol. Lett. 250, 163169.

Callon, C., Delbes, C., Duthoit, F., Montel, M.C., 2006. Application of SSCP-PCR fingerprinting to profile the yeast community in raw milk Salers cheeses. Syst. Appl. Microbiol. 29, 172-180.

Cardenas, E., Tiedje, J.M., 2008. New tools for discovering and characterizing microbial diversity. Curr. Opin. Biotechnol. 19, 544-549.

Carraro, L., Maifreni, M., Bartolomeoli, I., Martino, M.E., Novelli, E., Frigo, F., Marino, M., Cardazzo, B., 2011. Comparison of culture-dependent and -independent methods for bacterial community monitoring during Montasio cheese manufacturing. Res. Microbiol. 162, 231-239.

Casalta, E., Sorba, J.-M., Aigle, M., Ogier, J.-C., 2009. Diversity and dynamics of the microbial community during the manufacture of Calenzana, an artisanal Corsican cheese. Int. J. Food Microbiol. 133, 243-251.

Champagn, C.P., Ross, R.P., Saarela, M., Hansen, K.F., Charalampopoulos, D., 2011. Recommendations for the viability assessment of probiotics as concentrated cultures and in food matrices. Int. J. Food Microbiol. 149, 185-193.

Champagne, C.P., Raymond, Y., Tompkins, T.A., 2010. The determination of viable counts in probiotic cultures microencapsulated by spray-coating. Food Microbiol. 27, 11041111.

Chen, J., Zhang, L., Paoli, G.C., Shi, C., Tu, S.-I., Shi, X., 2010. A real-time PCR method for the detection of Salmonella enterica from food using a target sequence identified by comparative genomic analysis. Int. J. Food Microbiol. 137, 168-174.

Chiang, Y.-C., Fan, C.-M., Liao, W.-W., Lin, C.-K., Tsen, H.-Y., 2007. Real-Time PCR Detection of Staphylococcus aureus in Milk and Meat Using New Primers Designed from the Heat Shock Protein Gene htrA Sequence. J. Food Prot. 174; 70, 2855-2859.

Chomczynski, P., Sacchi, N., 1987. Single-step method of RNA isolation by acid guanidinium thiocyanate-phenol-chloroform extraction. Anal. Biochem. 162, 156159.

Cikos, S., Koppel, J., 2009. Transformation of real-time PCR fluorescence data to target gene quantity. Anal. Biochem. 384, 1-10.

Cocolin, L., Diez, A., Urso, R., Rantsiou, K., Comi, G., Bergmaier, I., Beimfohr, C., 2007. Optimization of conditions for profiling bacterial populations in food by cultureindependent methods. Int. J. Food Microbiol. 120, 100-109.

Cocolin, L., Innocente, N., Biasutti, M., Comi, G., 2004. The late blowing in cheese: a new molecular approach based on PCR and DGGE to study the microbial ecology of the alteration process. Int. J. Food Microbiol. 90, 83-91.

Cogan, T.M., John, W.F., 2011. Cheese - Microbiology of Cheese, Encyclopedia of Dairy Sciences, Academic Press, San Diego, pp. 625-631.

Coppola, S., Blaiotta, G., Ercolini, D., Moschetti, G., 2001. Molecular evaluation of microbial diversity occurring in different types of Mozzarella cheese. J. Appl. Microbiol. 90, 414-420.

Cressier, B., Bissonnette, N., 2011. Assessment of an extraction protocol to detect the major mastitis-causing pathogens in bovine milk. Journal of Dairy Science 94, 2171-2184.

Cretenet, M., Laroute, V., Ulve, V., Jeanson, S., Nouaille, S., Even, S., Piot, M., Girbal, L., Le Loir, Y., Loubiere, P., Lortal, S., Cocaign-Bousquet, M., 2011. Dynamic Analysis of 
the Lactococcus lactis Transcriptome in Cheeses Made from Milk Concentrated by Ultrafiltration Reveals Multiple Strategies of Adaptation to Stresses. Appl. Environ. Microbiol. 77, 247-257.

Delavenne, E., Mounier, J., Asmani, K., Jany, J.-L., Barbier, G., Le Blay, G., 2011. Fungal diversity in cow, goat and ewe milk. Int. J. Food Microbiol. 151, 247-251.

Delbes, C., Ali-Mandjee, L., Montel, M.-C., 2007. Monitoring Bacterial Communities in Raw Milk and Cheese by Culture-Dependent and -Independent 16S rRNA Gene-Based Analyses. Appl. Environ. Microbiol. 73, 1882-1891.

Delbes, C., Montel, M.C., 2005. Design and application of a Staphylococcus-specific single strand conformation polymorphism-PCR analysis to monitor Staphylococcus populations diversity and dynamics during production of raw milk cheese. Lett. Appl. Microbiol. 41, 169-174.

Dolci, Barmaz, Zenato, Pramotton, Alessandria, Cocolin, Rantsiou, Ambrosoli, 2009. Maturing dynamics of surface microflora in Fontina PDO cheese studied by culture-dependent and -independent methods. J. Appl. Microbiol. 106, 278-287.

Dolci, P., Alessandria, V., Rantsiou, K., Bertolino, M., Cocolin, L., 2010. Microbial diversity, dynamics and activity throughout manufacturing and ripening of Castelmagno PDO cheese. Int. J. Food Microbiol. 143, 71-75.

Donaghy, J.A., Rowe, M.T., Rademaker, J.L.W., Hammer, P., Herman, L., De Jonghe, V., Blanchard, B., Duhem, K., Vindel, E., 2008. An inter-laboratory ring trial for the detection and isolation of Mycobacterium avium subsp. paratuberculosis from raw milk artificially contaminated with naturally infected faeces. Food Microbiol. 25, 128-135.

Drisko, J., Bischoff, B., Giles, C., Adelson, M., Rao, R.V.S., McCallum, R., 2005. Evaluation of five probiotic products for label claims by DNA extraction and polymerase chain reaction analysis. Dig. Dis. Sci. 50, 1113-1117.

Duquenne, M., Fleurot, I., Aigle, M., Darrigo, C., Borezee-Durant, E., Derzelle, S., Bouix, M., Deperrois-Lafarge, V., Delacroix-Buchet, A., 2010. Tool for Quantification of Staphylococcal Enterotoxin Gene Expression in Cheese. Appl. Environ. Microbiol. 76, 1367-1374.

Duthoit, F., Godon, J.-J., Montel, M.-C., 2003. Bacterial community dynamics during production of registered designation of origin salers cheese as evaluated by $16 \mathrm{~S}$ rRNA gene single-strand conformation polymorphism analysis. Appl. Environ. Microbiol. 69, 3840-3848.

Duthoit, F., Tessier, L., Montel, M.C., 2005. Diversity, dynamics and activity of bacterial populations in 'Registered Designation of Origin' Salers cheese by single-strand conformation polymorphism analysis of $16 \mathrm{~S}$ rRNA genes. J. Appl. Microbiol. 98, 1198-1208.

El-Baradei, G., Delacroix-Buchet, A., Ogier, J.-C., 2007. Biodiversity of Bacterial Ecosystems in Traditional Egyptian Domiati Cheese. Appl. Environ. Microbiol. 73, 1248-1255.

Ercolini, D., Frisso, G., Mauriello, G., Salvatore, F., Coppola, S., 2008. Microbial diversity in natural whey cultures used for the production of Caciocavallo Silano PDO cheese. Int. J. Food Microbiol. 124, 164-170.

Ercolini, D., Hill, P.J., Dodd, C.E.R., 2003. Bacterial community structure and location in Stilton cheese. Appl. Environ. Microbiol. 69, 3540-3548. 
Ercolini, D., Mauriello, G., Blaiotta, G., Moschetti, G., Coppola, S., 2004. PCR-DGGE fingerprints of microbial succession during a manufacture of traditional water buffalo mozzarella cheese. J. Appl. Microbiol. 96, 263-270.

Ercolini, D., Moschetti, G., Blaiotta, G., Coppola, S., 2001. The potential of a polyphasic PCRdGGE approach in evaluating microbial diversity of natural whey cultures for water-buffalo Mozzarella cheese production: bias of culture-dependent and culture-independent analyses. Syst. Appl. Microbiol. 24, 610-617.

Falentin, H., Henaff, N., Le Bivic, P., Deutsch, S.-M., Parayre, S., Richoux, R., Sohier, D., Thierry, A., Lortal, S., Postollec, F., 2012. Reverse transcription quantitative PCR revealed persistency of thermophilic lactic acid bacteria metabolic activity until the end of the ripening of Emmental cheese. Food Microbiol. 29, 132-140.

Falentin, H., Postollec, F., Parayre, S., Henaff, N., Le Bivic, P., Richoux, R., Thierry, A., Sohier, D., 2010. Specific metabolic activity of ripening bacteria quantified by realtime reverse transcription PCR throughout Emmental cheese manufacture. Int. J. Food Microbiol. 144, 10-19.

FAO/WHO, 2002. Guidelines for the Evaluation of Probiotics in Food. London, Ontario, Canada. April 30 and May 1, 2002.

Fernandez, M., del Rio, B., Linares, D.M., Martin, M.C., Alvarez, M.A., 2006. Real-time polymerase chain reaction for quantitative detection of histamine-producing bacteria: use in cheese production. J. Dairy Sci. 89, 3763-3769.

Feurer, C., Irlinger, F., Spinnler, H.E., Glaser, P., Vallaeys, T., 2004a. Assessment of the rind microbial diversity in a farm house-produced $v s$ a pasteurized industrially produced soft red-smear cheese using both cultivation and rDNA-based methods. J. Appl. Microbiol. 97, 546-556.

Feurer, C., Vallaeys, T., Corrieu, G., Irlinger, F., 2004b. Does smearing inoculum reflect the bacterial composition of the smear at the end of the ripening of a french soft, redsmear cheese? J. Dairy Sci. 87, 3189-3197.

Fittipaldi, M., Codony, F., Adrados, B., Camper, A.K., Morato, J., 2011. Viable Real-Time PCR in Environmental Samples: Can All Data Be Interpreted Directly? Micr. Ecol. 61, 7-12.

Flórez, A.B., Mayo, B., 2006. Microbial diversity and succession during the manufacture and ripening of traditional, Spanish, blue-veined Cabrales cheese, as determined by PCR-DGGE. Int. J. Food Microbiol. 110, 165-171.

Fontana, C., Cappa, F., Rebecchi, A., Cocconcelli, P.S., 2010. Surface microbiota analysis of Taleggio, Gorgonzola, Casera, Scimudin and Formaggio di Fossa Italian cheeses. Int. J. Food Microbiol. 138, 205-211.

Fortina, M.G., Ricci, G., Mora, D., Parini, C., Manachini, P.L., 2001. Specific identification of Lactobacillus helveticus by PCR with pepC, pepN and htrA targeted primers. FEMS Microb. Lett. 198, 85-89.

Freeman, W.M., Walker, S.J., Vrana, K.E., 1999. Quantitative RT-PCR: pitfalls and potential. BioTechniques 26, 112-122, 124-125.

Friedrich, U., Lenke, J., 2006. Improved enumeration of lactic acid bacteria in mesophilic dairy starter cultures by using multiplex quantitative real-time PCR and flow cytometry-fluorescence in situ hybridization. Appl. Environ. Microbiol. 72, 41634171. 
Fujimoto, J., Tanigawa, K., Kudo, Y., Makino, H., Watanabe, K., 2011. Identification and quantification of viable Bifidobacterium breve strain Yakult in human faeces by using strain-specific primers and propidium monoazide. J. Appl. Microbiol. 110, 209-217.

Fuka, M.M., Engel, M., Skelin, A., Redzepovic, S., Schloter, M., 2010. Bacterial communities associated with the production of artisanal Istrian cheese. Int. J. Food Microbiol. $142,19-24$.

Fumian, T.M., Leite, J.P.G., Marin, V.A., Miagostovich, M.P., 2009. A rapid procedure for detecting noroviruses from cheese and fresh lettuce. J. Virol. Methods 155, 39-43.

Furet, J.-P., Quenée, P., Tailliez, P., 2004. Molecular quantification of lactic acid bacteria in fermented milk products using real-time quantitative PCR. Int. J. Food Microbiol. 97, 197-207.

Fusco, V., Quero, G.M., Morea, M., Blaiotta, G., Visconti, A., 2011. Rapid and reliable identification of Staphylococcus aureus harbouring the enterotoxin gene cluster (egc) and quantitative detection in raw milk by real time PCR. Int. J. Food Microbiol. 144, 528-537.

Gala, E., Landi, S., Solieri, L., Nocetti, M., Pulvirenti, A., Giudici, P., 2008. Diversity of lactic acid bacteria population in ripened Parmigiano Reggiano cheese. Int. J. Food Microbiol. 125, 347-351.

Garcia-Cayuela, T., Tabasco, R., Pelaez, C., Requena, T., 2009. Simultaneous detection and enumeration of viable lactic acid bacteria and bifidobacteria in fermented milk by using propidium monoazide and real-time PCR. Int. Dairy J. 19, 405-409.

Giannino, M.L., Marzotto, M., Dellaglio, F., Feligini, M., 2009. Study of microbial diversity in raw milk and fresh curd used for Fontina cheese production by cultureindependent methods. Int. J. Food Microbiol. 130, 188-195.

Grattepanche, F., Lacroix, C., Audet, P., Lapointe, G., 2005. Quantification by real-time PCR of Lactococcus lactis subsp. cremoris in milk fermented by a mixed culture. Appl. Microbiol. Biotechnol. 66, 414-421.

Hein, I., Jorgensen, H.J., Loncarevic, S., Wagner, M., 2005. Quantification of Staphylococcus aureus in unpasteurised bovine and caprine milk by real-time PCR. Res. Microbiol. 156, 554-563.

Hein, I., Lehner, A., Rieck, P., Klein, K., Brandl, E., Wagner, M., 2001. Comparison of different approaches to quantify Staphylococcus aureus cells by real-time quantitative PCR and application of this technique for examination of cheese. Appl. Environ. Microbiol. 67, 3122-3126.

Henri-Dubernet, S., Desmasures, N., Guéguen, M., 2004. Culture-dependent and cultureindependent methods for molecular analysis of the diversity of lactobacilli in "Camembert de Normandie" cheese. Lait 84, 179-189.

Henri-Dubernet, S., Desmasures, N., Gueguen, M., 2008. Diversity and dynamics of lactobacilli populations during ripening of RDO Camembert cheese. Can. J. Microbiol. 54, 218-228.

Herman, L., Block, J.d., Renterghem, R.v., 1997. Isolation and detection of Clostridium tyrobutyricum cells in semi-soft and hard cheeses using the polymerase chain reaction. J. Dairy Res. 64, 311-314.

Herman, L., Deridder, H., 1993. Cheese Components Reduce the Sensitivity of Detection of Listeria monocytogenes by the Polymerase Chain-Reaction. Neth. Milk Dairy J. 47, 2329. 
Herthnek, D., Nielsen, S.S., Lindberg, A., Bölske, G., 2008. A robust method for bacterial lysis and DNA purification to be used with real-time PCR for detection of Mycobacterium avium subsp. paratuberculosis in milk. J. Microbiol. Meth. 75, 335-340.

Karns, J.S., Van Kessel, J.S., McClusky, B.J., Perdue, M.L., 2007. Incidence of Escherichia coli O157:H7 and E. coli Virulence Factors in US Bulk Tank Milk as Determined by Polymerase Chain Reaction. J. Dairy Sci. 90, 3212-3219.

Kramer, M., Obermajer, N., Bogovic Matijasic, B., Rogelj, I., Kmetec, V., 2009. Quantification of live and dead probiotic bacteria in lyophilised product by real-time PCR and by flow cytometry. Appl. Microbiol. Biotechnol. 84, 1137-1147.

La Gioia, F., Rizzotti, L., Rossi, F., Gardini, F., Tabanelli, G., Torriani, S., 2011. Identification of a Tyrosine Decarboxylase Gene (tdcA) in Streptococcus thermophilus 1TT45 and Analysis of Its Expression and Tyramine Production in Milk. Appl. Environ. Microbiol. 77, 1140-1144.

Ladero, V., Fernández, M., Alvarez, M.A., 2009. Effect of post-ripening processing on the histamine and histamine-producing bacteria contents of different cheeses. Int. Dairy J. 19, 759-762.

Ladero, V., Martínez, N., Martín, M.C., Fernández, M., Alvarez, M.A., 2008. qPCR for quantitative detection of tyramine-producing bacteria in dairy products. Food Res. Int. 43, 289-295.

Lafarge, V., Ogier, J.C., Girarda, V., Maladena, V., Leveau, J.Y., Delacroix-Buchet, A., 2004. Le potentiel de la TTGE pour l'étude bactérienne de quelques laits crus. Lait 84, 169-178.

Larpin, S., Mondoloni, C., Goerges, S., Vernoux, J.-P., Gueguen, M., Desmasures, N., 2006. Geotrichum candidum dominates in yeast population dynamics in Livarot, a French red-smear cheese. FEMS Yeast Res. 6, 1243-1253.

Le Bourhis, A.G., Dore, J., Carlier, J.P., Chamba, J.F., Popoff, M.R., Tholozan, J.L., 2007. Contribution of $C$. beijerinckii and $C$. sporogenes in association with $C$. tyrobutyricum to the butyric fermentation in Emmental type cheese. Int. J. Food Microbiol. 113, 154-163.

Le Bourhis, A.G., Saunier, K., Dore, J., Carlier, J.P., Chamba, J.F., Popoff, M.R., Tholozan, J.L., 2005. Development and validation of PCR primers to assess the diversity of Clostridium spp. in cheese by temporal temperature gradient gel electrophoresis. Appl. Environ. Microbiol. 71, 29-38.

Le Dréan, G., Mounier, J., Vasseur, V., Arzur, D., Habrylo, O., Barbier, G., 2010. Quantification of Penicillium camemberti and P. roqueforti mycelium by real-time PCR to assess their growth dynamics during ripening cheese. Int. J. Food Microbiol. $138,100-107$.

Lee, Z.M.-P., Bussema, C., Schmidt, T.M., 2009. rrnDB: documenting the number of rRNA and tRNA genes in bacteria and archaea. Nucleic Acids Res. 37, D489-D493.

Li, W.J., Raoult, D., Fournier, P.E., 2009. Bacterial strain typing in the genomic era. FEMS Microbiol. Rev. 33, 892-916.

Liao, D., 1999. Concerted evolution: molecular mechanism and biological implications. Am. J. Hum. Genet. 64, 24-30.

Lopez-Enriquez, L., Rodriguez-Lazaro, D., Hernandez, M., 2007. Quantitative Detection of Clostridium tyrobutyricum in Milk by Real-Time PCR. Appl. Environ. Microbiol. 73, 3747-3751. 
Makhzami, S., Quenee, P., Akary, E., Bach, C., Aigle, M., Delacroix-Buchet, A., Ogier, J.C., Serror, P., 2008. In situ gene expression in cheese matrices: application to a set of enterococcal genes. J. Microbiol. Meth. 75, 485-490.

Makino, H., Fujimoto, J., Watanabe, K., 2010. Development and evaluation of a real-time quantitative PCR assay for detection and enumeration of yeasts of public health interest in dairy products. Int. J. Food Microbiol. 140, 76-83.

Manuzon, M.Y., Hanna, S.E., Luo, H., Yu, Z., Harper, W.J., Wang, H.H., 2007. Quantitative Assessment of the Tetracycline Resistance Gene Pool in Cheese Samples by RealTime TaqMan PCR. Appl. Environ. Microbiol. 73, 1676-1677.

Marianelli, C., Martucciello, A., Tarantino, M., Vecchio, R., Iovane, G., Galiero, G., 2008. Evaluation of Molecular Methods for the Detection of Brucella Species in Water Buffalo Milk. J. Dairy Sci. 91, 3779-3786.

Martin, M.C., Martinez, N., Rio, B.d., Ladero, V., Fernandez, M., Alvarez, M.A., 2010. A novel real-time polymerase chain reaction-based method for the detection and quantification of lactose-fermenting Enterobacteriaceae in the dairy and other food industries. J. Dairy Sci. 93, 860-867.

Marzotto, M., Maffeis, C., Paternoster, T., Ferrario, R., Rizzotti, L., Pellegrino, M., Dellaglio, F., Torriani, S., 2006. Lactobacillus paracasei A survives gastrointestinal passage and affects the fecal microbiota of healthy infants. Res. Microbiol. 157, 857-866.

Masco, L., Huys, G., De Brandt, E., Temmerman, R., Swings, J., 2005. Culture-dependent and culture-independent qualitative analysis of probiotic products claimed to contain bifidobacteria. Int. J. Food Microbiol. 102, 221-230.

Masco, L., Vanhoutte, T., Temmerman, R., Swings, J., Huys, G., 2007. Evaluation of real-time PCR targeting the $16 \mathrm{~S}$ rRNA and recA genes for the enumeration of bifidobacteria in probiotic products. Int. J. Food Microbiol. 113, 351-357.

Masoud, W., Takamiya, M., Vogensen, F.K., Lillevang, S., Al-Soud, W.A., Sørensen, S.J., Jakobsen, M., 2011. Characterization of bacterial populations in Danish raw milk cheeses made with different starter cultures by denaturating gradient gel electrophoresis (DGGE) and pyrosequencing. Int. Dairy J. 21, 142-148.

Maurer, J.J., 2011. Rapid Detection and Limitations of Molecular Techniques. Ann. Rev. Food Sci. Techn., Vol 2 2, 259-279.

Mauriello, G., Moio, L., Genovese, A., Ercolini, D., 2003. Relationships between flavoring capabilities, bacterial composition, and geographical origin of natural whey cultures used for traditional water-buffalo mozzarella cheese manufacture. J. Dairy Sci. 86, 486-497.

McKillip, J.L., Jaykus, L.A., Drake, M.A., 2000. A comparison of methods for the detection of Escherichia coli O157:H7 from artificially-contaminated dairy products using PCR. J. Appl. Microbiol. 89, 49-55.

Monnet, C., Back, A., Irlinger, F., 2012 (in press). Growth of Aerobic Ripening bacteria at the Cheese Surface is Limited by the Availability of Iron. Appl. Environ. Microbiol.

Monnet, C., Correia, K., Sarthou, A.-S., Irlinger, F., 2006. Quantitative detection of Corynebacterium casei in cheese by real-time PCR. Appl. Environ. Microbiol. 72, 6972-6979.

Monnet, C., Ulvé, V., Sarthou, A.-S., Irlinger, F., 2008. Extraction of RNA from cheese without prior separation of microbial cells. Appl. Environ. Microbiol. 74, 5724-5730. 
Moschetti, G., Blaiotta, G., Villani, F., Coppola, S., 2001. Nisin-producing organisms during traditional 'Fior di latte' cheese-making monitored by multiplex-PCR and PFGE analyses. Int. J. Food Microbiol. 63, 109-116.

Mounier, J., Blay, G.L., Vasseur, V., Floch, G.L., Jany, J.L., Barbier, G., 2010. Application of denaturing high-performance liquid chromatography (DHPLC) for yeasts identification in red smear cheese surfaces. Lett. Appl. Microbiol. 51, 18-23.

Mounier, J., Monnet, C., Jacques, N., Antoinette, A., Irlinger, F., 2009. Assessment of the microbial diversity at the surface of Livarot cheese using culture-dependent and independent approaches. Int. J. Food Microbiol. 133, 31-37.

Muller, J.A., Stanton, C., Sybesma, W., Fitzgerald, G.F., Ross, R.P., 2010. Reconstitution conditions for dried probiotic powders represent a critical step in determining cell viability. J. Appl. Microbiol. 108, 1369-1379.

Neefs, J., Van de Peer, Y., De Rijk, P., Chapelle, S., De Wachter, R., 1993. Compilation of small ribosomal subunit RNA structures. Nucleic Acids Res. 21, 3025-3049.

Nicolaisen, M.H., Baelum, J., Jacobsen, C.S., Sorensen, J., 2008. Transcription dynamics of the functional tfdA gene during MCPA herbicide degradation by Cupriavidus necator AEO106 (pRO101) in agricultural soil. Environ. Microbiol. 10, 571-579.

Niederhauser, C., Candrian, U., Hofelein, C., Jermini, M., Buhler, H.P., Luthy, J., 1992. Use of Polymerase Chain-Reaction for Detection of Listeria monocytogenes in Food. Appl. Environ. Microbiol. 58, 1564-1568.

Nikolic, M., Terzic-Vidojevic, A., Jovcic, B., Begovic, J., Golic, N., Topisirovic, L., 2008. Characterization of lactic acid bacteria isolated from Bukuljac, a homemade goat's milk cheese. Int. J. Food Microbiol. 122, 162-170.

Nocker, A., Cheung, C.Y., Camper, A.K., 2006. Comparison of propidium monoazide with ethidium monoazide for differentiation of live vs. dead bacteria by selective removal of DNA from dead cells. J. Microbiol. Meth. 67, 310-320.

Nocker, A., Mazza, A., Masson, L., Camper, A.K., Brousseau, R., 2009. Selective detection of live bacteria combining propidium monoazide sample treatment with microarray technology. J. Microbiol. Meth. 76, 253-261.

Nocker, A., Richter-Heitmann, T., Montijn, R., Schuren, F., Kort, R., 2010. Discrimination between live and dead cells in bacterial communities from environmental water samples analyzed by 454 pyrosequencing. Int. Microbiol. 13, 59-65.

Nogva, H.K., Dromtorp, S.M., Nissen, H., Rudi, K., 2003. Ethidium monoazide for DNAbased differentiation of viable and dead bacteria by 5 '-nuclease PCR. Biotechniques 34, 804-813.

Nolan, T., Hands, R.E., Bustin, S.A., 2006. Quantification of mRNA using real-time RT-PCR. Nature Protocols 1, 1559-1582.

Ogier, J.-C., Lafarge, V., Girard, V., Rault, A., Maladen, V., Gruss, A., Leveau, J.-Y., Delacroix-Buchet, A., 2004. Molecular fingerprinting of dairy microbial ecosystems by use of Temporal Temperature and Denaturing Gradient Gel Electrophoresis. Appl. Environ. Microbiol. 70, 5628-5643.

Ogier, J.-C., Son, O., Gruss, A., Tailliez, P., Delacroix-Buchet, A., 2002. Identification of the bacterial microflora in dairy products by temporal temperature gradient gel electrophoresis. Appl. Environ. Microbiol. 68, 3691-3701. 
O'Grady, J., Ruttledge, M., Sedano-Balbas, S., Smith, T.J., Barry, T., Maher, M., 2009. Rapid detection of Listeria monocytogenes in food using culture enrichment combined with real-time PCR. Food Microbiol. 26, 4-7.

Omiccioli, E., Amagliani, G., Brandi, G., Magnani, M., 2009. A new platform for Real-Time PCR detection of Salmonella spp., Listeria monocytogenes and Escherichia coli O157 in milk. Food Microbiol. 26, 615-622.

Ongol, M.P., Tanaka, M., Sone, T., Asano, K., 2009. A real-time PCR method targeting a gene sequence encoding 16S rRNA processing protein, rimM, for detection and enumeration of Streptococcus thermophilus in dairy products. Food Res. Int. 42, 893898.

Parayre, S., Falentin, H., Madec, M.N., Sivieri, K., Le Dizes, A.S., Sohier, D., Lortal, S., 2007. Easy DNA extraction method and optimisation of PCR-Temporal Temperature Gel Electrophoresis to identify the predominant high and low GC-content bacteria from dairy products. J. Microbiol. Meth. 69, 431-441.

Peng, M., Smith, A.H., Rehberger, T.G., 2011. Quantification of Propionibacterium acidipropionici P169 Bacteria in Environmental Samples by Use of Strain-Specific Primers Derived by Suppressive Subtractive Hybridization. Appl. Environ. Microbiol. 77, 3898-3902.

Postollec, F., Falentin, H., Pavan, S., Combrisson, J., Sohier, D., 2011. Recent advances in quantitative PCR (qPCR) applications in food microbiology. Food Microbiol. 28, 848-861.

Rademaker, J.L.W., Hoolwerf, J.D., Wagendorp, A.A., te Giffel, M.C., 2006. Assessment of microbial population dynamics during yoghurt and hard cheese fermentation and ripening by DNA population fingerprinting. Int. Dairy J. 16, 457-466.

Rademaker, J.L.W., Peinhopf, M., Rijnen, L., Bockelmann, W., Noordman, W.H., 2005. The surface microflora dynamics of bacterial smear-ripened Tilsit cheese determined by T-RFLP DNA population fingerprint analysis. Int. Dairy J. 15, 785-794.

Randazzo, C.L., Pitino, I., Ribbera, A., Caggia, C., 2010. Pecorino Crotonese cheese: Study of bacterial population and flavour compounds. Food Microbiol. 27, 363-374.

Randazzo, C.L., Torriani, S., Akkermans, A.D.L., de Vos, W.M., Vaughan, E.E., 2002. Diversity, dynamics, and activity of bacterial communities during production of an artisanal sicilian cheese as evaluated by $16 \mathrm{~S}$ rRNA analysis. Appl. Environ. Microbiol. 68, 1882-1785.

Randazzo, C.L., Vaughan, E.E., Caggia, C., 2006. Artisanal and experimental Pecorino Siciliano cheese: microbial dynamics during manufacture assessed by culturing and PCR-DGGE analyses. Int. J. Food Microbiol. 109, 1-8.

Rantsiou, K., Alessandria, V., Urso, R., Dolci, P., Cocolin, L., 2008a. Detection, quantification and vitality of Listeria monocytogenes in food as determined by quantitative PCR. Int. J. Food Microbiol. 121, 99-105.

Rantsiou, K., Comi, G., Cocolin, L., 2004. The rpoB gene as a target for PCR-DGGE analysis to follow lactic acid bacterial population dynamics during food fermentations. Food Microbiol. 21, 481-487.

Rantsiou, K., Urso, R., Dolci, P., Comi, G., Cocolin, L., 2008b. Microflora of Feta cheese from four Greek manufacturers. Int. J. Food Microbiol. 126, 36-42. 
Rasolofo, E.A., St-Gelais, D., LaPointe, G., Roy, D., 2010. Molecular analysis of bacterial population structure and dynamics during cold storage of untreated and treated milk. Int. J. Food Microbiol. 138, 108-118.

Reimann, S., Grattepanche, F., Rezzonico, E., Lacroix, C., 2010. Development of a real-time RT-PCR method for enumeration of viable Bifidobacterium longum cells in different morphologies. Food Microbiol. 27, 236-242.

Rinttila, T., Kassinen, A., Malinen, E., Krogius, L., Palva, A., 2004. Development of an extensive set of $16 \mathrm{~S}$ rDNA-targeted primers for quantification of pathogenic and indigenous bacteria in faecal samples by real-time PCR. J. Appl. Microbiol. 97, 1166-1177.

Rodríguez-Lázaro, D., D'Agostino, M., Herrewegh, A., Pla, M., Cook, N., Ikonomopoulos, J., 2005. Real-time PCR-based methods for detection of Mycobacterium avium subsp. paratuberculosis in water and milk. Int. J. Food Microbiol. 101, 93-104.

Rossen, L., Norskov, P., Holmstrom, K., Rasmussen, O.F., 1992. Inhibition of Pcr by Components of Food Samples, Microbial Diagnostic Assays and DNA-Extraction Solutions. Int. J. Food Microbiol. 17, 37-45.

Rossetti, B.C., Frey, J., Pilo, P., 2010. Direct detection of Mycoplasma bovis in milk and tissue samples by real-time PCR. Mol. Cell. Probes 24, 321-323.

Rossi, F., Gardini, F., Rizzotti, L., La Gioia, F., Tabanelli, G., Torriani, S., 2011. Quantitative Analysis of Histidine Decarboxylase Gene (hdcA) Transcription and Histamine Production by Streptococcus thermophilus PRI60 under Conditions Relevant to Cheese Making. Appl. Environ. Microbiol. 77, 2817-2822.

Rossmanith, P., Krassnig, M., Wagner, M., Hein, I., 2006. Detection of Listeria monocytogenes in food using a combined enrichment/real-time PCR method targeting the prfA gene. Res. Microbiol. 157, 763-771.

Rossmanith, P., Su, B., Wagner, M., Hein, I., 2007. Development of matrix lysis for concentration of gram positive bacteria from food and blood. J. Microbiol. Meth. 69, 504-511.

Rudi, K., Naterstad, K., Dromtorp, S.M., Holo, H., 2005. Detection of viable and dead Listeria monocytogenes on gouda-like cheeses by real-time PCR. Lett. Appl. Microbiol. 40, 301-306.

Rueckert, A., Ronimus, R.S., Morgan, H.W., 2005. Development of a rapid detection and enumeration method for thermophilic bacilli in milk powders. J. Microbiol. Meth. 60, 155-167.

Sanchez, J.I., Rossetti, L., Martinez, B., Rodriguez, A., Giraffa, G., 2006. Application of reverse transcriptase PCR-based T-RFLP to perform semi-quantitative analysis of metabolically active bacteria in dairy fermentations. J. Microbiol. Meth. 65, 268-277.

Saubusse, M., Millet, L., Delbes, C., Callon, C., Montel, M.C., 2007. Application of Single Strand Conformation Polymorphism --PCR method for distinguishing cheese bacterial communities that inhibit Listeria monocytogenes. Int. J. Food Microbiol. 116, 126-135.

Selinger, D.W., Saxena, R.M., Cheung, K.J., Church, G.M., Rosenow, C., 2003. Global RNA Half-Life Analysis in Escherichia coli Reveals Positional Patterns of Transcript Degradation. Genome Res. 13, 216-223. 
Serhan, M., Cailliez-Grimal, C., Borges, F., Revol-Junelles, A.M., Hosri, C., Fanni, J., 2009. Bacterial diversity of Darfiyeh, a Lebanese artisanal raw goat's milk cheese. Food Microbiol. 26, 645-652.

Serpe, L., Gallo, P., Fidanza, N., Scaramuzzo, A., Fenizia, D., 1999. Single-step method for rapid detection of Brucella spp. in soft cheese by gene-specific polymerase chain reaction. J. Dairy Res. 66, 313-317.

Singh, J., Batish, V.K., Grover, S., 2009. A scorpion probe-based real-time PCR assay for detection of E. coli O157:H7 in dairy products. Foodborne Pathog. Dis. 6, 395-400.

Slana, I., Kralik, P., Kralova, A., Pavlik, I., 2008. On-farm spread of Mycobacterium avium subsp. paratuberculosis in raw milk studied by IS900 and F57 competitive real time quantitative PCR and culture examination. Int. J. Food Microbiol. 128, 250-257.

Smeianov, V.V., Wechter, P., Broadbent, J.R., Hughes, J.E., Rodriguez, B.T., Christensen, T.K., Ardo, Y., Steele, J.L., 2007. Comparative High-Density Microarray Analysis of Gene Expression during Growth of Lactobacillus helveticus in Milk versus Rich Culture Medium. Appl. Environ. Microbiol. 73, 2661-2672.

Songjinda, P., Nakayama, J., Tateyama, A., Tanaka, S., Tsubouchi, M., Kiyohara, C., Shirakawa, T., Sonomoto, K., 2007. Differences in developing intestinal microbiota between allergic and non-allergic infants: A pilot study in apan. Biosci. Biotechn. Biochem. 71, 2338-2342.

Stephan, R., Schumacher, S., Tasara, T., Grant, I.R., 2007. Prevalence of Mycobacterium avium Subspecies paratuberculosis in Swiss Raw Milk Cheeses Collected at the Retail Level. J. Dairy Sci. 90, 3590-3595.

Stevens, K.A., Jaykus, L.A., 2004. Direct detection of bacterial pathogens in representative dairy products using a combined bacterial concentration-PCR approach. J. Appl. Microbiol. 97, 1115-1122.

Studer, E., Schaeren, W., Naskova, J., Pfaeffli, H., Kaufmann, T., Kirchhofer, M., Steiner, A., Graber, H.U., 2008. A Longitudinal Field Study to Evaluate the Diagnostic Properties of a Quantitative Real-Time Polymerase Chain Reaction-Based Assay to Detect Staphylococcus aureus in Milk. J. Dairy Sci. 91, 1893-1902.

Taïbi, A., Dabour, N., Lamoureux, M., Roy, D., LaPointe, G., 2011. Comparative transcriptome analysis of Lactococcus lactis subsp. cremoris strains under conditions simulating Cheddar cheese manufacture. Int. J. Food Microbiol. 146, 263-275.

Temmerman, R., Scheirlinck, I., Huys, G., Swings, J., 2003. Culture-independent analysis of probiotic products by denaturing gradient gel electrophoresis. Appl. Environ. Microbiol. 69, 220-226.

Thevenard, B., Rasoava, N., Fourcassié, P., Monnet, V., Boyaval, P., Rul, F., 2011. Characterization of Streptococcus thermophilus two-component systems: In silico analysis, functional analysis and expression of response regulator genes in pure or mixed culture with its yogurt partner, Lactobacillus delbrueckii subsp. bulgaricus. Int. J. Food Microbiol. 151, 171-181.

Torriani, S., Zapparoli, G., Dellaglio, F., 1999. Use of PCR-based methods for rapid differentiation of Lactobacillus delbrueckii subsp. bulgaricus and L. delbrueckii subsp. lactis. Appl. Environ. Microbiol. 65, 4351-4356.

Treven, P., Trmcic, A., Obermajer, T., Rogelj, I., Bogovic Matijasic, B. Prevalence of gassericin K7 A and K7 B gene determinants in the Lactobacillus acidophilus group and in adult faecal microbiota, submitted. 
Trmcic, A., Monnet, C., Rogelj, I., Bogovic Matijasic, B., 2011. Expression of nisin genes in cheese-A quantitative real-time polymerase chain reaction approach. J. Dairy Sci. 94, 77-85.

Trmcic, A., Obermajer, T., Rogelj, I., Bogovic Matijasic, B., 2008. Short Communication: Culture-Independent Detection of Lactic Acid Bacteria Bacteriocin Genes in Two Traditional Slovenian Raw Milk Cheeses and Their Microbial Consortia. J. Dairy Sci. 91, 4535-4541.

Ulvé, V.M., Monnet, C., Valence, F., Fauquant, J., Falentin, H., Lortal, S., 2008. RNA extraction from cheese for analysis of in situ gene expression of Lactococcus lactis. J. Appl. Microbiol. 105, 1327-1333.

Van Hoorde, K., Heyndrickx, M., Vandamme, P., Huys, G., 2010. Influence of pasteurization, brining conditions and production environment on the microbiota of artisan Gouda-type cheeses. Food Microbiol. 27, 425-433.

Van Hoorde, K., Verstraete, T., Vandamme, P., Huys, G., 2008. Diversity of lactic acid bacteria in two Flemish artisan raw milk Gouda-type cheeses. Food Microbiol. 25, 929-935.

Vandesompele, J., De Preter, K., Pattyn, F., Poppe, B., Van Roy, N., De Paepe, A., Speleman, F., 2002. Accurate normalization of real-time quantitative RT-PCR data by geometric averaging of multiple internal control genes. Genome Biology 3, research0034.0031 - research0034.0011.

Vitali, B., Candela, M., Matteuzzi, D., Brigidi, P., 2003. Quantitative detection of probiotic Bifidobacterium strains in bacterial mixtures by using real-time PCR. Syst. Appl. Microbiol. 26, 269-276.

Wong, M.L., Medrano, J.F., 2005. Real-time PCR for mRNA quantitation. BioTechniques 39, 75-85.

Zago, M., Bonvini, B., Carminati, D., Giraffa, G., 2009. Detection and quantification of Enterococcus gilvus in cheese by real-time PCR. Syst. Appl. Microbiol. 32, 514-521.

Zoric Peternel, M., Canzek Majhenic, Andreja, Holo, Helge, Nes, Ingolf, Salehian, Zhian, Berlec, Ales, Rogelj, Irena., 2010. Wide-inhibitory spectra bacteriocins produced by Lactobacillus gasseri K7, Probiotics \& Antimicro. Prot. 2, 233-240. 


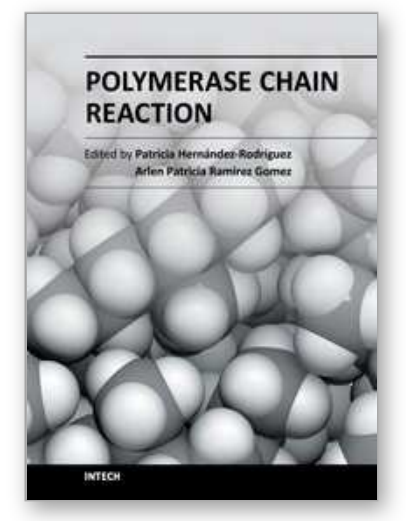

\author{
Polymerase Chain Reaction \\ Edited by Dr Patricia Hernandez-Rodriguez
}

ISBN 978-953-51-0612-8

Hard cover, 566 pages

Publisher InTech

Published online 30, May, 2012

Published in print edition May, 2012

This book is intended to present current concepts in molecular biology with the emphasis on the application to animal, plant and human pathology, in various aspects such as etiology, diagnosis, prognosis, treatment and prevention of diseases as well as the use of these methodologies in understanding the pathophysiology of various diseases that affect living beings.

\title{
How to reference
}

In order to correctly reference this scholarly work, feel free to copy and paste the following:

Christophe Monnet and Bojana Bogovic Matijasic (2012). Application of PCR-Based Methods to Dairy Products and to Non-Dairy Probiotic Products, Polymerase Chain Reaction, Dr Patricia Hernandez-Rodriguez (Ed.), ISBN: 978-953-51-0612-8, InTech, Available from: http://www.intechopen.com/books/polymerase-chainreaction/application-of-pcr-based-methods-to-dairy-products-and-to-non-dairy-probiotic-products

\section{INTECH}

open science | open minds

\author{
InTech Europe \\ University Campus STeP Ri \\ Slavka Krautzeka 83/A \\ 51000 Rijeka, Croatia \\ Phone: +385 (51) 770447 \\ Fax: +385 (51) 686166 \\ www.intechopen.com
}

\section{InTech China}

Unit 405, Office Block, Hotel Equatorial Shanghai

No.65, Yan An Road (West), Shanghai, 200040, China

中国上海市延安西路65号上海国际贵都大饭店办公楼 405 单元

Phone: +86-21-62489820

Fax: +86-21-62489821 
(C) 2012 The Author(s). Licensee IntechOpen. This is an open access article distributed under the terms of the Creative Commons Attribution 3.0 License, which permits unrestricted use, distribution, and reproduction in any medium, provided the original work is properly cited. 